NBER WORKING PAPER SERIES

\title{
RENT-SHARING, HOLDUP, AND WAGES: \\ EVIDENCE FROM MATCHED PANEL DATA
}

\author{
David Card \\ Francesco Devicienti \\ Agata Maida \\ Working Paper 16192 \\ http://www.nber.org/papers/w16192
}

\author{
NATIONAL BUREAU OF ECONOMIC RESEARCH \\ 1050 Massachusetts Avenue \\ Cambridge, MA 02138 \\ July 2010
}

We thank Raj Chetty, Carlo Gianelle, Peter Kuhn, Alex Lefter, Bentley MacLeod, Enrico Moretti, Luigi Pistaferri, Ben Sand, and seminar participants at the LABORatorio Revelli, Berkeley IRLE, and the Federal Reserve Board of San Francisco for comments and suggestions. We are especially grateful to Giuseppe Tattara for providing the Veneto Work History Data, and to Carlo Gianelle and Marco Valentini for assistance in using these data. Agata Maida is pleased to acknowledge support from the Leibniz Association though the Labor Market Institutions project at RWI-Essen. The views expressed herein are those of the authors and do not necessarily reflect the views of the National Bureau of Economic Research.

NBER working papers are circulated for discussion and comment purposes. They have not been peerreviewed or been subject to the review by the NBER Board of Directors that accompanies official NBER publications.

(C) 2010 by David Card, Francesco Devicienti, and Agata Maida. All rights reserved. Short sections of text, not to exceed two paragraphs, may be quoted without explicit permission provided that full credit, including $\odot$ notice, is given to the source. 
Rent-sharing, Holdup, and Wages: Evidence from Matched Panel Data

David Card, Francesco Devicienti, and Agata Maida

NBER Working Paper No. 16192

July 2010

JEL No. J31

\begin{abstract}
$\underline{\text { ABSTRACT }}$
When wage contracts are relatively short-lived, rent sharing may reduce the incentives for investment since some of the returns to sunk capital are captured by workers. In this paper we use a matched worker-firm data set from the Veneto region of Italy that combines Social Security earnings records for employees with detailed financial information for employers to measure the degree of rent sharing and test for holdup. We estimate wage models with job match effects, allowing us to control for any permanent differences in productivity across workers, firms, and job matches. We also compare OLS and instrumental variables specifications that use sales of firms in other regions of the country to instrument value-added per worker. We find strong evidence of rent-sharing, with a "Lester range" of variation in wages between profitable and unprofitable firms of around $10 \%$. On the other hand we find little evidence that bargaining lowers the return to investment. Instead, firm-level bargaining in Veneto appears to split the rents after deducting the full cost of capital. Our findings are consistent with a dynamic bargaining model (Crawford, 1988) in which workers pay up front for the returns to sunk capital they will capture in later periods.
\end{abstract}

David Card

Department of Economics

549 Evans Hall, \#3880

University of California, Berkeley

Berkeley, CA 94720-3880

and NBER

card@econ.berkeley.edu

Francesco Devicienti

University of Torino Faculty of Economics

Corso Unione Sovietica 218bis

10134 Torino

ITALY

fdevic@tiscali.it
Agata Maida

5: , प( WHQ

Hohenzollernstr. 1-3

Essen 45128

GERMANY

agata.maida@laboratoriorevelli.it 
A long-running strand of research has argued that employees share some of the rents earned by their employers. ${ }^{1}$ Early studies used data on wages and profitability at the industry level (e.g., Slichter, 1950; de Menil, 1971; Dickens and Katz, 1986) while later studies use firmlevel data (e.g., Nickell and Wadhwani, 1990; Chistofides and Oswald, 1992; Abowd and Lemieux, 1993; Blanchflower, Oswald and Sanfey, 1996; Hildreth and Oswald, 1997; Arai, 2003). Both literatures show a positive correlation between profitability and wages. How much of this is due to the sorting of high-ability workers to high-profit industries or firms is still unclear. Recent studies that use matched worker/firm data to control for unobserved ability find smaller but generally significant effects of profitability on wages (e.g., Margolis and Salvanes, 2001; Martins, 2009; Guertzgen, forthcoming). ${ }^{2}$

In a dynamic setting it is well known that bargaining over rents can lead to a "holdup" problem (Baldwin, 1983; Grout, 1984; Che and Sakovics, 2008; MacLeod, 2010). Specifically, when capital is sunk, bargaining over quasi-rents can divert some of the return on investment to workers, potentially causing firms to under-invest. ${ }^{3}$ Building on this insight, Connolly et al.

${ }^{1}$ The idea of rent-sharing by a cartel of workers appears in Adam Smith (1976, Book I, Chapter 8). The post-war neo-institutionalists (e.g., Lester, 1952, Slichter, 1950) emphasized firm profitability (or ability to pay) as an important determinant of wages. De Menil (1971) laid out the basic model of bargaining that we use in this paper and has been adopted by many subsequent authors (e.g., Svejnar, 1986; Abowd and Lemieux, 1993; Blanchflower, Oswald and Sanfey, 1996).

${ }^{2}$ Guiso, Pistaferri, and Schivardi (2005) study the effect of firm-specific productivity shocks on employee wages using a matched longitudinal data set similar to ours. Although their empirical analysis focuses on risk sharing, rather than rent-sharing, their results suggest that firm-level productivity shocks have a positive effect on wages.

${ }^{3}$ The problem was recognized by Simons (1944) who wrote: "Frankly, I can see no reason why strongly organized workers, in an industry where huge investment is already sunk in highly durable assets, should ever permit a return on investment sufficient to attract new capital." 
(1986), Denny and Nickell (1992), and Bronars and Deere (1993) have argued that unionized firms invest less than their non-union competitors, contributing to the decline in union coverage in many countries (see also Addison and Hirsch, 1989, and Hirsch, 2004). ${ }^{4}$

In this paper we use a matched data set that combines administrative earnings records for individual employees with detailed balance sheet data for their employers to measure the degree of rent sharing by firms in the Veneto region of Italy. We implement a simple test for the presence of holdup based on the fraction of capital costs that are deducted from the quasi-rent expression in the wage determination model. When capital costs are fully deducted firms have the right incentives to invest. When some of the returns to previous investments are included as quasi-rent, however, firms that invest more will pay higher wages in the future, generating a holdup problem.

Our estimation sample includes about 400,000 workers and 7,000 firms, with wages and detailed financial information covering the period from 1995 to 2001 . These data enable us to estimate wage models that include job match effects (i.e., dummies for each worker-firm pair observed in the sample), as well as time-varying worker and firm variables. Match effects control for any permanent differences between workers, firms, and job-matches. For about three-quarters of the sample we can also identify the minimum wage specified by the sector-wide contract that covers the employment relationship. ${ }^{5}$ Thus, we can measure the wage premium that

\footnotetext{
${ }^{4}$ As shown by Crawford (1988) holdup does not necessarily arise in long term relationships governed by short term contracts. It should also be noted that not all previous studies have found that unionized firms have lower investment rates - see e.g., Machin and Wadhwani (1991).

${ }^{5}$ In Italy contracts negotiated at the sector-level between national unions and employer groups are extended to cover essentially all employees. The sectoral contracts specify minimum wages by industry and occupation category (typically 5 or more categories).
} 
arises through a combination of firm-level contracting and individual bargaining. ${ }^{6}$ In an institutional setting like Italy with binding sectoral contracts, this premium is arguably the appropriate earnings concept for measuring firm-specific rent-sharing. ${ }^{7}$

We relate individual earnings to a firm-specific quasi-rent measure, defined as value added per worker net of the opportunity cost of labor and some share of the cost of capital per worker. A longstanding concern in the rent-sharing literature is the potential endogeneity of profitability, arising through efficiency wage effects or other channels. ${ }^{8}$ A related problem is measurement error in value added, which is likely to be exacerbated by a within-spell estimation strategy. To address both issues we use the revenues of firms in the same narrowly defined sector in other regions of Italy to construct an instrumental variable for value-added per worker for employers in Veneto. Our identifying assumption is that industry demand shocks affect firmlevel profitability but have no direct effect on local labor supply.

Our empirical findings point to two main conclusions. First, consistent with existing studies, we find that more profitable employers pay higher wages. In simple cross-sectional models the estimated elasticity of wages with respect to quasi-rents per worker is on the order of 6-8\%. Within-job-spell estimates obtained by OLS are substantially smaller, but appear to be attenuated by measurement errors and transitory fluctuations in value-added. When we

${ }^{6}$ During our sample period about $40 \%$ of workers were covered by firm-level contracts that set pay scales above the sectoral minimum.

${ }^{7}$ Cristini and Leoni (2007) specify a two-level bargaining model that describes the determination of the sector wide minimum wages and the firm-specific wage premium. We abstract from the first and concentrate on the second.

${ }^{8}$ See e.g., Abowd and Lemieux (1993) and Van Reenen (1996). These authors are most concerned about the possibility that more profitable firms hire high-ability workers. As noted, by including job match dummies we control for any permanent differences in ability between employees (including differences that are rewarded more highly in some firms than others). 
instrument value-added using data for firms in the same sector in other regions we obtain estimates of the rent sharing elasticity in the range of 3-4\% - roughly one-half as large as the cross-sectional estimates. Second, our estimates suggest that firm-level bargaining in Italy is driven by a quasi-rent measure that deducts the full cost of capital. Though we cannot rule out a small degree of holdup, the point estimates from a range of specifications are consistent with an implicit user cost of capital of around $10 \%$ - close to the benchmark suggested by several recent studies (Arachi and Biagi, 2005; Elston and Rondi, 2006).

Full offset of capital costs is consistent with a dynamic bargaining model in which workers pay up-front for the portion of returns to sunk investments they will capture in future bargaining (Crawford, 1988). In such a model the appropriate expression for the quasi-rent contains a deduction for the cost of the non-irreversible share of the current capital stock, plus a deduction for future holdup of the irreversible share of future capital. When the firm's capital stock is growing at the real interest rate the sum of these deductions equals the full cost of capital.

\section{A Model of Rent Sharing and Wage Determination}

In this section we outline a simple dynamic model of wage bargaining between a firm and a collection of identical workers. We assume that wages are renegotiated every period, and that some fraction of the current capital stock is sunk, and cannot be resold by the firm during the current period. ${ }^{9}$ Although this is a textbook setting for holdup (e.g., Cahuc and Zylberberg, 2004, pp. 543-545) we show that the holdup problem is mitigated when bargaining today anticipates

\footnotetext{
${ }^{9}$ Thus, we are modeling a long term relationship governed by incomplete short term contracts. Our model is an adaptation of the one presented in Crawford (1988).
} 
rent-sharing tomorrow. Instead, as in Becker's (1962) on-the-job training model, workers make an up-front contribution by accepting lower wages today in return for a share of future quasirents. When workers and firms share the same discount rate and workers' bargaining power is constant over time this restores the incentive for firms to invest efficiently.

\section{a. Basic Model with Fixed Employment}

We start with the case where employment is fixed at L. We adopt a two-period model and assume that the firm's revenue in period $t$ (net of raw materials costs) is $R\left(K_{t}, \theta_{t}\right)$ where $\theta_{t}$ is a fully anticipated demand shock and $\mathrm{K}_{\mathrm{t}}$ is the firm's capital stock, assumed to be determined one period in advance. The firm's profit in period $t$ is:

$$
\mathrm{R}\left(\mathrm{K}_{\mathrm{t}}, \theta_{\mathrm{t}}\right)-\mathrm{w}_{\mathrm{t}} \mathrm{L}-\mathrm{r}_{\mathrm{t}} \mathrm{K}_{\mathrm{t}}
$$

where $w_{t}$ represents the negotiated wage and $r_{t}$ represents the user cost of capital. We assume that workers' preferences over wage outcomes in period $t$ are represented by the excess wage bill:

$$
\mathrm{u}\left(\mathrm{w}_{\mathrm{t}}, \mathrm{L}\right)=\left(\mathrm{w}_{\mathrm{t}}-\mathrm{m}_{\mathrm{t}}\right) \mathrm{L}
$$

where $\mathrm{m}_{\mathrm{t}}$ represents in the opportunity cost of labor. ${ }^{10}$ Finally, we assume that the parties discount the future at a common discount rate $\beta$.

In the second period the only decision variable is the wage, $w_{2}$. Following de Menil (1971) and subsequent authors we assume that $\mathrm{w}_{2}$ is determined by generalized Nash bargaining:

$$
\mathrm{w}_{2}=\underset{\mathrm{w}}{\operatorname{argmax}}\left[\mathrm{u}(\mathrm{w}, \mathrm{L})-\mathrm{u}_{2}^{0}\right]^{\gamma}\left[\pi\left(\mathrm{w}, \mathrm{r}_{2} ; \mathrm{K}_{2}, \mathrm{~L}, \theta_{2}\right)-\pi_{2}^{0}\right]^{1-\gamma},
$$

${ }^{10}$ In our empirical work we assume that $\mathrm{m}_{\mathrm{t}}$ is either the minimum sectoral wage, or the average wage in the sector. The assumption of an excess wage bill objective means that in a setting with variable employment, the surplus-maximizing choice of employment equates the marginal product of labor to the outside wage $\mathrm{m}_{\mathrm{t}}$. 
where $\mathrm{u}_{2}^{0}$ and $\pi_{2}^{0}$ represent the fallback positions of the parties if no agreement is reached, and $\gamma$ represents the relative bargaining power of workers. On the workers' side we assume that $u_{2}^{0}=$ 0 . On the firm's side we assume that a fraction $\delta$ of the capital stock can be resold for other uses in the event of no agreement. ${ }^{11}$ In this case, the fallback position of the firm is a net cash flow of $-(1-\delta) \mathrm{r}_{2} \mathrm{~K}_{2}$. Combining these assumptions with equation (1), the second period wage maximizes:

$$
\left[\left(\mathrm{w}_{2}-\mathrm{m}_{2}\right) \mathrm{L}\right]^{\gamma}\left[\mathrm{R}\left(\mathrm{K}_{2}, \theta_{2}\right)-\mathrm{w}_{2} \mathrm{~L}-\delta \mathrm{r}_{2} \mathrm{~K}_{2}\right]^{1-\gamma} .
$$

The associated first order condition for $\mathrm{w}_{2}$ can be re-arranged as:

$$
\mathrm{w}_{2}=\mathrm{m}_{2}+\gamma \mathrm{Q}_{2} / \mathrm{L}
$$

where

$$
\mathrm{Q}_{2} \equiv \mathrm{R}\left(\mathrm{K}_{2}, \theta_{2}\right)-\mathrm{m}_{2} \mathrm{~L}-\delta \mathrm{r}_{2} \mathrm{~K}_{2}
$$

is the "quasi-rent" associated with reaching agreement in period 2. Notice that when $\delta=1$, investment is reversible and the appropriate quasi-rent is value-added minus the opportunity cost of labor minus the full cost of capital. On the other hand, when $\delta=0$, all investment is sunk and the appropriate quasi-rent is value-added minus the opportunity cost of labor.

The second period profits of the firm are:

$$
\begin{aligned}
\pi_{2} & =(1-\gamma) \mathrm{Q}_{2}-(1-\delta) \mathrm{r}_{2} \mathrm{~K}_{2}, \\
& =(1-\gamma)\left[\mathrm{R}\left(\mathrm{K}_{2}, \theta_{2}\right)-\mathrm{m}_{2} \mathrm{~L}\right]-\mathrm{r}_{2}(1-\gamma \delta) \mathrm{K}_{2} .
\end{aligned}
$$

Differentiating the second line with respect to $\mathrm{K}_{2}$ yields:

$$
\partial \pi_{2} / \partial \mathrm{K}_{2}=(1-\gamma)\left[\partial \mathrm{R} / \partial \mathrm{K}_{2}-\mathrm{r}_{2}(1-\gamma \delta) /(1-\gamma)\right] .
$$

If the firm chooses $\mathrm{K}_{2}$ to maximize second period profits, this first order condition implies that it

\footnotetext{
${ }^{11} \mathrm{~A}$ similar assumption is made by Grout (1984) who distinguishes between the price
} 
will under invest whenever $\delta<1$. In particular, when a fraction $1-\delta$ of investment is sunk, the firm acts as if the user cost of capital is $r_{2}(1-\gamma \delta) /(1-\gamma)>r_{2}$. For this reason a number of previous authors have concluded that short term bargaining with sunk investment imposes a "tax" on capital. ${ }^{12}$

The intuition underlying equation (5) is potentially misleading, however, because it fails to recognize that the outcome of bargaining in period 1 will in general depend on the expected outcomes of bargaining in period 2. ${ }^{13}$ Assume that the parties bargain in period 1 anticipating the returns in period 2 implied by the wage bargain of equation (3) (i.e., net utility of $\left(\mathrm{w}_{2}-\mathrm{m}_{2}\right) \mathrm{L}=$ $\gamma \mathrm{Q}_{2}$ and profits specified in equation (4)). As in period 2, assume that the fallback position of workers in the event of no agreement in period 1 is a payoff of 0 (for one period), while the fallback for the firm is a cash flow of $-\mathrm{r}_{1}(1-\delta) \mathrm{K}_{1}$. In this case, bargaining in period 1 will maximize the expression

$$
\left.\left[\left(\mathrm{w}_{1}-\mathrm{m}_{1}\right) \mathrm{L}+\beta \gamma \mathrm{Q}_{2}\right]^{\gamma}\left[\mathrm{R}\left(\mathrm{K}_{1}, \theta_{1}\right)-\mathrm{w}_{1} \mathrm{~L}-\delta \mathrm{r}_{1} \mathrm{~K}_{1}+\beta\left((1-\gamma) \mathrm{Q}_{2}-\mathrm{r}_{2}(1-\delta) \mathrm{K}_{2}\right)\right)\right]^{1-\gamma} \text {. }
$$

As was emphasized in the efficient contracting literature (e.g., MacDonald and Solow, 1981; Brown and Ashenfelter, 1986) it is potentially important to consider whether $\mathrm{w}_{1}$ and $\mathrm{K}_{2}$ are jointly determined in period 1 , or whether the firm selects $K_{2}$ unilaterally before $\mathrm{w}_{1}$ is determined. For the moment, consider the case where $\mathrm{K}_{2}$ is jointly determined. Then it is easily shown that maximization of $(6)$ requires $\partial \mathrm{R}\left(\mathrm{K}_{2}, \theta_{2}\right) / \partial \mathrm{K}_{2}=\mathrm{r}_{2}$, i.e., an "efficient" level of

paid for capital and its resale value.

${ }^{12}$ For example, Cahuc and Zylberberg (2004, pp. 543-545) present a simple analysis of the sunk investment case that yields essentially the same formula as equation (5) with $\delta=0$.

${ }^{13}$ The same point was made by Becker (1962) in an analysis of the return to general human capital investments. 
investment. $^{14}$

Turning to the wage, the first order condition for $\mathrm{w}_{1}$ can be written as:

$$
\begin{aligned}
& \mathrm{w}_{1}-\mathrm{m}_{1}=\gamma \mathrm{Q}_{1} / \mathrm{L}, \quad \text { where } \\
& \mathrm{Q}_{1} \equiv \mathrm{R}\left(\mathrm{K}_{1}, \theta_{1}\right)-\mathrm{m}_{1} \mathrm{~L}-\delta \mathrm{r}_{1} \mathrm{~K}_{1}-\beta(1-\delta) \mathrm{r}_{2} \mathrm{~K}_{2} .
\end{aligned}
$$

Note that when the bargaining relationship is expected to continue the effective quasi-rent in period 1 deducts a fraction $\delta$ of current capital costs, and a complementary fraction $1-\delta$ of future costs (discounted by $\beta$ ). In essence, the firm is compensated ex ante for the share of returns to capital it will lose due to rent sharing in the second period. Note that if the return to capital is constant $\left(r_{1}=r_{2}=r\right)$ and the capital stock is growing at the "steady state" rate $1 / \beta$ then $K_{2}=K_{1} / \beta$ and the quasi-rent expression becomes:

$$
\mathrm{Q}_{1}=\mathrm{R}\left(\mathrm{K}_{1}, \theta_{1}\right)-\mathrm{m}_{1} \mathrm{~L}-\mathrm{rK}_{1} \text {. }
$$

In this case the appropriate expression for the quasi-rent deducts the full cost of capital even though capital is sunk.

Importantly, the expression for $\mathrm{w}_{1}$ in equation (7) remains the same whether $\mathrm{K}_{2}$ is determined jointly by the parties, or whether the firm chooses $\mathrm{K}_{2}$ unilaterally, prior to wage bargaining in period 1. In the latter case equations (4) and (7) can be combined to show that:

$$
\begin{gathered}
\pi_{1}+\beta \pi_{2}=(1-\gamma)\left[\mathrm{R}\left(\mathrm{K}_{1}, \theta_{1}\right)-\mathrm{m}_{1} \mathrm{~L}-\delta \mathrm{r}_{1} \mathrm{~K}_{1}\right]-\gamma(1-\delta) \mathrm{r}_{1} \mathrm{~K}_{1} \\
+\beta(1-\gamma)\left[\mathrm{R}\left(\mathrm{K}_{2}, \theta_{2}\right)-\mathrm{m}_{2} \mathrm{~L}-\mathrm{r}_{2} \mathrm{~K}_{2}\right] .
\end{gathered}
$$

An immediate implication is that

${ }^{14}$ For a maximand of the form $[\mathrm{a}+\mathrm{bw}+\mathrm{g}(\mathrm{K})]^{\gamma}[\mathrm{c}-\mathrm{bw}+\mathrm{h}(\mathrm{K})]^{1-\gamma}$, if w and $\mathrm{K}$ are the choice variables and there are no constraints on $\mathrm{w}$ the first order conditions require that $\mathrm{g}^{\prime}(\mathrm{K})+\mathrm{h}^{\prime}(\mathrm{K})=0$. In this setup $\mathrm{w}$ is an efficient transfer and any bargaining solution requires a surplus-maximizing choice of $\mathrm{K}$. In applying this observation to (6) note that the sum of the second period payoffs to workers and the firm is equal to $R\left(K_{2}, L, \theta_{2}\right)-m_{2} L-r_{2} K_{2}$. 


$$
\partial\left[\pi_{1}+\beta \pi_{2}\right] / \partial \mathrm{K}_{2}=\beta(1-\gamma)\left[\partial \mathrm{R}\left(\mathrm{K}_{2}, \theta_{2}\right) / \partial \mathrm{K}_{2}-\mathrm{r}_{2}\right]
$$

When first period wages are determined by (7), the firm will unilaterally set the marginal product of capital in period 2 equal to $r_{2}$, implementing the jointly optimal decision. Thus, holdup in period 2 has no distortionary effect on the choice of capital $\mathrm{K}_{2}$.

This rather surprising conclusion depends on two critical assumptions: (1) workers' preferences are linear in wages; (2) the parties share a common discount rate. Under these assumptions the bargaining parties have identical linear preferences over wage streams, and Crawford (1988) shows that short-term contracting can fully internalize the effect of future bargaining over relationship-specific quasi rents. ${ }^{15}$

\section{b. Allowing for Variable Employment}

To consider the case of variable employment we proceed in two steps. First, we assume that employment is jointly determined, as in the efficient contracting models of Svejnar (1986) and Brown and Ashenfelter (1986). In this case the predictions of the fixed employment model remain intact: wage-setting fully anticipates opportunistic bargaining in the future, eliminating the effect of holdup on investment. We then consider a "right to manage" model in which the parties bargain over wages and the firm sets employment unilaterally. This creates a distortion in employment. Nevertheless, the investment choices of firm remain approximately efficient.

Allowing for variable employment and assuming that wages and employment are determined jointly, the first order conditions for $\mathrm{w}_{2}$ and $\mathrm{L}_{2}$ require:

$$
\mathrm{w}_{2}=\mathrm{m}_{2}+\gamma \mathrm{Q}_{2} / \mathrm{L}_{2} \quad \text { and } \quad \partial \mathrm{R}\left(\mathrm{L}_{2}, \mathrm{~K}_{2}, \theta_{2}\right) / \partial \mathrm{L}_{2}=\mathrm{m}_{2}
$$

${ }^{15}$ In our setting we also need to assume that the relative bargaining power of workers is constant over time. Manning (1987) presents an interesting analysis of sequential bargaining over wages and employment in which workers' bargaining power is different in different stages. 
where

$$
\mathrm{Q}_{2}=\mathrm{R}\left(\mathrm{L}_{2}, \mathrm{~K}_{2}, \theta_{2}\right)-\mathrm{m}_{2} \mathrm{~L}_{2}-\delta \mathrm{r}_{2} \mathrm{~K}_{2}
$$

Likewise, the first order conditions for the optimal choices of $\mathrm{w}_{1}$ and $\mathrm{L}_{1}$ require

$$
\mathrm{w}_{1}=\mathrm{m}_{1}+\gamma \mathrm{Q}_{1} / \mathrm{L}_{1} \quad \text { and } \partial \mathrm{R}\left(\mathrm{L}_{1}, \mathrm{~K}_{1}, \theta_{1}\right) / \partial \mathrm{L}_{1}=\mathrm{m}_{1} \text {, }
$$

where

$$
\mathrm{Q}_{1}=\mathrm{R}\left(\mathrm{L}_{1}, \mathrm{~K}_{1}, \theta_{1}\right)-\mathrm{m}_{1} \mathrm{~L}_{1}-\delta \mathrm{r}_{1} \mathrm{~K}_{1}-\beta(1-\delta) \mathrm{r}_{2} \mathrm{~K}_{2} .
$$

Finally, the optimal choice for $\mathrm{K}_{2}$ (which we assume is also made in period 1) requires

$$
\mathrm{r}_{2}=\partial \mathrm{R}\left(\mathrm{L}_{2}, \mathrm{~K}_{2}, \theta_{2}\right) / \partial \mathrm{K}_{2} .
$$

The expressions for $\mathrm{w}_{1}$ and $\mathrm{w}_{2}$ are the same as in the fixed employment case, except that $\mathrm{L}$ is replaced by the efficient level of employment that equates the marginal product of labor with the outside wage $\mathrm{m}_{\mathrm{t}}$. The expression for the firm's discounted profits also remains the same as in equation (9) (with the appropriate substitution for $\mathrm{L}_{\mathrm{t}}$ ), implying that the firm unilaterally selects the jointly optimal investment choice when wages and employment are jointly determined in a sequence of short-term bargains. Consequently, with jointly determined employment, holdup does not distort investment.

When the firm sets employment unilaterally the analysis is more complicated because now wages have three competing functions: to split the surplus between the parties; to regulate incentives for investment; and to allocate labor within the period. The conflict between these objectives causes some inefficiency. In particular, with unilateral employment setting any bargained wage above the alternative wage implies that employment is set below the efficient choice that maximizes the joint surplus of the parties. To first order, however, this distortion does not spill over to investment: as in the fixed employment case the negotiated wage contains a 
discount for future holdup, and the level of capital selected by the firm sets the marginal product of capital approximately equal to the interest rate.

Specifically, in Appendix A we show that when: (i) the firm sets employment taking the wage as given; (ii) wage bargaining maximizes a generalized Nash objective with a fixed weight $\gamma$ for workers; and (iii) the negotiated mark-up over the alternative wage is approximately constant over time; the first-period wage is approximately

$$
\begin{aligned}
& \mathrm{w}_{1}=\mathrm{m}_{1}+\gamma \mathrm{Q}_{1}{ }^{*} / \mathrm{L}_{1}{ }^{*} \text {, where } \\
& \mathrm{Q}_{1}{ }^{*}=\mathrm{R}\left(\mathrm{L}_{1}{ }^{*}, \mathrm{~K}_{1}, \theta_{1}\right)-\mathrm{m}_{1} \mathrm{~L}_{1}{ }^{*}-\delta \mathrm{r}_{1} \mathrm{~K}_{1}-\beta(1-\delta) \mathrm{r}_{2} \mathrm{~K}_{2}{ }^{*}
\end{aligned}
$$

and

$$
\mathrm{L}_{1}^{*}=\mathrm{L}_{1}\left(\mathrm{~m}_{\mathrm{t}}, \mathrm{K}_{1}, \theta_{1}\right)
$$

are the "efficient" levels of quasi-rent and employment, respectively, $\mathrm{K}_{1}$ is the initial capital stock (inherited from the past), and $\mathrm{K}_{2}{ }^{*}$ is the "efficient" capital stock in period 2 (defined precisely in the Appendix). ${ }^{16}$ Moreover, as in the simple case with fixed employment, the firm selects the efficient capital stock $\mathrm{K}_{2}{ }^{*}$.

These results imply that when the firm sets investment and employment unilaterally, $\mathrm{w}_{1}$ and $\mathrm{K}_{2}$ will be set at (approximately) the same levels as would occur under joint employment setting. However, the firm's employment choice $\mathrm{L}_{1}$ will be below the efficient level, $\mathrm{L}_{1}{ }^{*}$, and the observed measure of rents in period 1 will differ from the measure $\mathrm{Q}_{1}{ }^{*}$ that determines wages. In particular, we show in Appendix A that the observed measure of rents in period 1 is:

$$
\mathrm{Q}_{1}=\mathrm{R}\left(\mathrm{L}_{1}, \mathrm{~K}_{1}, \theta_{1}\right)-\mathrm{m}_{1} \mathrm{~L}_{1}-\delta \mathrm{r}_{1} \mathrm{~K}_{1}-\beta(1-\delta) \mathrm{r}_{2} \mathrm{~K}_{2}
$$

${ }^{16}$ The derivation of these expressions uses a linearization of the firm's profit functions in each period around the profit associated with the outside wage $\left(\mathrm{m}_{1}\right.$ or $\left.\mathrm{m}_{2}\right)$. Assuming that $\gamma$ is on the order of $10-20 \%$ and the ratio of profits to the wage bill is in the range of 0 to 1 , the percentage wage markup implied by (10) is under $20 \%$ and the assumption of local linearity is reasonable. The average markup of wages over the sectoral minimum in our sample ranges from $23 \%$ to $26 \%$, so we believe condition (iii) is reasonable. 


$$
\approx \mathrm{Q}_{1}{ }^{*}\left(1+\varepsilon \gamma \mathrm{g}_{1}{ }^{*}\right)
$$

where $\varepsilon \leq 0$ is the elasticity of the firm's labor demand schedule and $\mathrm{g}_{1}{ }^{*} \equiv\left(\mathrm{w}_{1}-\mathrm{m}_{1}\right) / \mathrm{m}_{1}$ is the negotiated markup of the contract wage over the outside wage. Approximating $\mathrm{L}_{1}=$

$\mathrm{L}_{1}^{*}\left(1+\varepsilon \mathrm{g}_{1}^{*}\right)$, the "efficient" quasi-rent per worker is

$$
\begin{aligned}
\mathrm{Q}_{1}{ }^{*} / \mathrm{L}_{1}{ }^{*} & =\lambda \mathrm{Q}_{1} / \mathrm{L}_{1}, \quad \text { where } \\
\lambda & \approx\left(1+\varepsilon \mathrm{g}_{1}{ }^{*}(1-\gamma)\right) \leq 1 .
\end{aligned}
$$

Thus, observed quasi-rent per worker overstates the appropriate expression $\mathrm{Q}_{1}{ }^{*} / \mathrm{L}_{1}{ }^{*}$ in the wage determination model. For example, assuming a demand elasticity of $\varepsilon=-1$, a rent-share parameter of $\gamma=0.20$, and a markup of $\mathrm{g}_{1}{ }^{*}=0.15$, the implied value of $\lambda$ is approximately 0.9 .

\section{c. Empirical Implementation}

In the derivation of equation (10) we assumed that capital is homogeneous and that a fraction $\delta$ of the capital stock in each period can be put to other uses during a dispute, leading to a quasi-rent measure of the form:

$$
\mathrm{Q}_{\mathrm{t}}^{*}=\mathrm{R}\left(\mathrm{L}_{\mathrm{t}}^{*}, \mathrm{~K}_{\mathrm{t}}, \theta_{\mathrm{t}}\right)-\mathrm{m}_{\mathrm{t}} \mathrm{L}_{\mathrm{t}}^{*}-\delta \mathrm{r}_{\mathrm{t}} \mathrm{K}_{\mathrm{t}}-\beta(1-\delta) \mathrm{r}_{\mathrm{t}+1} \mathrm{~K}_{\mathrm{t}+1}
$$

Since capital adjusts irregularly and is measured with some error, it is difficult to separately identify the effects of $\mathrm{K}_{\mathrm{t}}$ and $\mathrm{K}_{\mathrm{t}+1}$ on wages in any period. ${ }^{17}$ Moreover we do not have periodspecific estimates of the cost of capital. In view of these limitations we make the assumptions that $r_{t}=r_{t+1}=r$, and that the rate of growth of capital is close to the discount rate (i.e., $K_{t+1}=$ $\left.(1 / \beta) \mathrm{K}_{\mathrm{t}}\right)$. In this case, our bargaining model predicts that the appropriate quasi-rent measure for wage determination in period $\mathrm{t}$ is:

${ }^{17}$ Note however that prior to a large new investment workers are predicted to take a wage cut in anticipation of higher rents in the future. Such dynamic behavior is arguably the strongest 


$$
\mathrm{Q}_{\mathrm{t}}^{*}=\mathrm{R}\left(\mathrm{L}_{\mathrm{t}}^{*}, \mathrm{~K}_{\mathrm{t}}, \theta_{\mathrm{t}}\right)-\mathrm{m}_{\mathrm{t}} \mathrm{L}_{\mathrm{t}}^{*}-\mathrm{r} \mathrm{K}_{\mathrm{t}}
$$

Substituting this expression into equation (10) yields:

$$
\mathrm{w}_{\mathrm{t}}=\mathrm{m}_{\mathrm{t}}+\gamma\left[\mathrm{R}\left(\mathrm{L}_{\mathrm{t}}^{*}, \mathrm{~K}_{\mathrm{t}}, \theta_{\mathrm{t}}\right)-\mathrm{m}_{\mathrm{t}} \mathrm{L}_{\mathrm{t}}^{*}-\mathrm{r} \mathrm{K}_{\mathrm{t}}\right] / \mathrm{L}_{\mathrm{t}}^{*}
$$

and using (12) we obtain a relationship between wages and observed quasi-rents:

$$
\begin{aligned}
\mathrm{w}_{\mathrm{t}} & =\mathrm{m}_{\mathrm{t}}+\lambda \gamma\left[\mathrm{R}\left(\mathrm{L}_{\mathrm{t}}, \mathrm{K}_{\mathrm{t}}, \theta_{\mathrm{t}}\right)-\mathrm{m}_{\mathrm{t}} \mathrm{L}_{\mathrm{t}}-\mathrm{r} \mathrm{K}_{\mathrm{t}}\right] / \mathrm{L}_{\mathrm{t}} \\
& =\mathrm{m}_{\mathrm{t}}(1-\lambda \gamma)+\lambda \gamma \mathrm{R}\left(\mathrm{L}_{\mathrm{t}}, \mathrm{K}_{\mathrm{t}}, \theta_{\mathrm{t}}\right) / \mathrm{L}_{\mathrm{t}}-\lambda \gamma \mathrm{r}\left(\mathrm{K}_{\mathrm{t}} / \mathrm{L}_{\mathrm{t}}\right) .
\end{aligned}
$$

Inspection of equation (13) points to two immediate predictions: (1) value-added per worker affects wages with a coefficient $\lambda \gamma$ that understates the true rent-splitting parameter $\gamma$ to the extent that $\lambda<1$; (2) controlling for value-added per worker, capital per worker affects wages with a coefficient of $-\lambda \gamma r$. In contrast, in the presence of distortionary holdup, we would expect the coefficient of capital per worker to be smaller than $-\lambda \gamma \mathrm{r}$ (in absolute value). In the extreme case of complete holdup the predicted coefficient of capital per worker is 0 . Thus, our main empirical focus is on comparing the estimated effects of value-added per worker and capital per worker on negotiated wages, and testing whether the ratio is consistent with existing estimates of the cost of capital. We also compare the effects of different types of capital (e.g., physical versus working capital) and distinguish between firms with higher and lower levels of debt to check whether there is a larger offset for investments that are financed by debt (as suggested by Dasgupta and Sengupta, 1993).

The literature on capital investment in Italy suggests that during the mid-to-late 1990s a reasonable estimate of the user cost of capital is in the range of 8-12\%. Elston and Rondi (2006) report a distribution of estimates of the user cost of capital for publicly traded Italian firms in the

implication of our model. We thank Peter Kuhn for pointing this out. 
1995-2002 period, with a median of 11\% (Elston and Rondi, 2006, Table A4). Arachi and Biagi (2005) calculate the user cost of capital, with special attention to the tax treatment of investment, for a panel of larger firms over the 1982-1998 period. Their estimates for 1995-1998 are in the range of $10-15 \%$ with a value of $11 \%$ in 1998 (Arachi and Biagi, 2005, Figure 2). ${ }^{18}$

In our estimation we adopt a log-linearization of equation (13). Specifically, building on the observation that wages are approximately log-normally distributed, and that standard covariates like gender, age, and job tenure exert a proportional effect on wages, we fit models of the form:

$$
\log \left(\mathrm{w}_{\mathrm{it}}\right)=\log \left(\mathrm{a}_{\mathrm{it}}\right) \mathrm{b}_{1}+\mathrm{X}_{\mathrm{it}} \mathrm{b}_{2}+V A_{\mathrm{j}(\mathrm{i}, \mathrm{t}, \mathrm{t}} \mathrm{b}_{3}+K L_{\mathrm{j}(\mathrm{i}, \mathrm{t}), \mathrm{t}} \mathrm{b}_{4}+\xi_{\mathrm{it}}
$$

where $\mathrm{w}_{\mathrm{it}}$ is the average daily wage earned by worker $\mathrm{i}$ in year $\mathrm{t}, \mathrm{a}_{\mathrm{it}}$ is a (potentially noisy) measure of the opportunity wage for the worker in that year, $X_{\mathrm{it}}$ represents a vector of measured characteristics of the worker, $V A_{\mathrm{j}(\mathrm{i}, \mathrm{t}), \mathrm{t}}$ represents measured value-added per worker at the firm $\mathrm{j}(\mathrm{i}, \mathrm{t})$ that employed worker $\mathrm{i}$ in period $\mathrm{t}, K L_{\mathrm{j}(\mathrm{i}, \mathrm{t}), \mathrm{t}}$ is measured capital per worker at the firm, and $\xi_{\text {it }}$ is an error term. The prediction of no distortionary holdup implies that $b_{4}=-r b_{3}$, while full holdup implies $b_{4}=0$. We fit this model using a variety of estimation strategies, including OLS, OLS with firm-worker-match fixed effects, and instrumental variables (IV) with match fixed effects, treating value added per worker (and in some cases capital per worker) as endogenous.

${ }^{18}$ Franzosi (2008) calculates the marginal user cost of capital taking into account the differential costs of debt and equity financing, and the effects of tax reforms in 1996 and 1997. Her calculations suggest that the marginal user cost of capital was about $7.5 \%$ pre-1996 for a firm with 60\% debt financing, and fell to 6\% after 1997. 


\section{Institutional Background, Data Sources, and Descriptive Overview}

\section{a. Institutional Background}

Wage setting in Italy is characterized by a "two-level" bargaining system. ${ }^{19}$ Sectoral agreements (negotiated every two years) establish contractual minimum wages for different occupation classes that are automatically extended to all employees in the sector. Individual employers can negotiate supplemental local agreements with their workforce that provide wage premiums over and above the sectoral minimums. In the mid-1990s firm-level bargains covered approximately $10 \%$ of firms with at least 10 employees, and about $40 \%$ of all private sector employees nationwide (ISTAT, 2000). Employees also receive individual premiums and bonuses - including seniority adjustments - that add to the minimum contractual wage covering their job. As described below, our data allow us to identify the sectoral contract and occupation category for most workers, so in principle we know the sectoral minimum wage that applies to their jobs. We do not know whether a worker is covered by a firm-specific supplementary agreement. Conceptually, then, we think of wage bargaining as determining the sum of an individual-specific premium and any firm-wide premium paid as a result of a local contract (or for other reasons).

\section{b. Data Sources}

Our data set combines three types of information: individual earnings records, firm balance sheet data, and contractual minimum wage rates. The earnings data are derived from the Veneto Workers History (VWH) dataset, which was constructed by Giuseppe Tattara and

\footnotetext{
${ }^{19}$ This system was introduced in 1993, replacing an earlier system that included local and sectoral agreements and a national indexation formula. See Casadio (2003) and Dell'Aringa and Lucifora (1994). The Netherlands, Spain, and Portugal have similar two-level systems.
} 
colleagues at the University of Venezia using administrative records of the Italian Social Security System. ${ }^{20}$ The VWH contains information on private sector employees in the Veneto region over the period from 1975 to 2001 (see Tattara and Valentini, 2007). ${ }^{21}$ Specifically, it includes register-based information for any job that lasts at least one day.

On the employee side the VWH includes total earnings during the calendar year for each job, the number of days worked during the year, the appropriate national contract and level within that contract (i.e., a "job ladder" code), and the the worker's gender, age, region (or country) of birth, and seniority with the firm. On the employer side the VWH includes industry (classified by 5-digit ATECO 91), the dates of "birth" and closure of the firm (if applicable), the firm's location, and the firm's national tax number (codice fiscale).

Column 1 of Table 1 provides an overview of the sample of individual workers age 16-64 in the VWH over the 1995-2001 period (the period of overlap with the firm financial data). The sample includes just under 2 million individuals who were observed in 3.11 million job spells at 191,000 firms. On average $42 \%$ of Veneto workers are female, $45 \%$ are between the ages of 17 and $30,37 \%$ are between the ages of 31 and 44 , and $17 \%$ are age 45 or older. The mean daily wage (for jobs observed in 2000) was 65 Euros.

Firm-level balance sheet information was obtained from AIDA (analisi informatizzata delle aziende), a database distributed by Bureau Van Dijk that includes information for incorporated non-financial firms in Italy with annual sales of at least 500,000 Euros. ${ }^{22}$ AIDA

${ }^{20} \mathrm{We}$ are extremely grateful to Giuseppe Tattara for making available the dataset and to Marco Valentini and Carlo Gianelle for assistance in using it.

${ }^{21}$ The Veneto region has a population of about 4.6 million - approximately $8 \%$ of the total population of Italy.

${ }^{22} \mathrm{See}$ http://www.bvdep.com/en/aida.html. Only a tiny fraction of firms in AIDA are 16 
contains the official balance sheet data for these firms, and is available starting in 1995 . The AIDA data include sales, value added, total wage bill, capital, the total number of employees, industry (categorized by 5-digit code), and the firm's tax number.

Contractual minimum wage levels were obtained from records of the national contracts. We were able to reconstruct contractual wages over our sample period for a total of 23 major national contracts in construction, metal and mechanical engineering, textiles and clothing, food, furniture and wood products, trade, tourism, and services. We were unable to obtain information for one major sector - chemicals - and for other smaller sectoral contracts. For each occupation grade listed in the contract, we have information on the minimum wage, the cost-of-living allowance, and other special allowances. Typically, the contractual minimum wage levels are updated once or twice per year to reflect changes in the cost of living allowance.

\section{c. Matching the Worker and Firm Data}

We use tax code identifiers to match job-year observations for employees age 16 to 64 in the VWH to employer information in AIDA for the period from 1995 to 2001. The match rate is relatively high: we were able to find at least one observation in the VHW for over $95 \%$ of the firms in AIDA sample. We evaluated the quality of the matches by comparing the total number of workers in the VWH who are recorded as having a job at a given firm (in October of a given year) with the total number of employees reported in AIDA (for the same year). In general the two counts agree very closely. To reduce the influence of false matches (particularly for larger firms) we decided to eliminate a small number of matches for which the absolute difference

publicly traded. We exclude these firms and those with consolidated balance sheets (i.e., holding companies). 
between the number of employees reported in the balance sheet and the number found in the VWH exceeded 100. Removing these "gross outliers" (less than $1 \%$ of all firms) the correlation between the number of employees in the balance sheet and the number found in the VWH is 0.99. (A plot of the two measures against each other, available on request, shows that most of the points lie very close to the 45 degree line). We also compared total wages and salaries for the calendar year as reported in AIDA with total wage payments reported for employees in the VWH. The two measures are highly correlated (correlation $>0.98$ ), and the median ratio between them is close to 1.0 .

Column 2 of Table 1 shows the characteristics of the job-year observations we successfully matched to AIDA. About one-half of all workers observed between 1995 and 2001 in the VWH can be matched to an AIDA firm. Most of the non-matches appear to be employees of small firms that are excluded from AIDA. We were able to match at least one worker for about 18,000 firms, or about $10 \%$ of the total universe of firms contained in the VWH. Average firm size for the matched jobs sample (36.0 employees) is substantially above the average for all firms in the VWH (7.0 employees). Mean daily wages for the matched observations are also higher, while the fractions of female and younger workers are lower.

From the set of potential matches described in column 2 we made a series of exclusions to arrive at our estimation sample. First, we eliminated job-year observations for jobs that lasted only part of a year. Second, we eliminated apprentices, managers, and part-time employees, as well as employees in construction. ${ }^{23}$ Finally, we eliminated jobs at firms that had fewer than 15

\footnotetext{
${ }^{23} \mathrm{We}$ also eliminated workers in one small textile industry (furs), and several other industries with a relatively small number of firms outside the Veneto area. The latter restriction was adopted to improve the power of our instrumental variables strategy, which relies on revenue shocks at firms outside Veneto. Elimination of these sectors does not change the basic OLS rent sharing models (in Table 2)
} 
employees or closed during the calendar year, and job-year observations with unusually high or low values for several key firm-level variables, including value added per worker and capital per worker. The characteristics of the resulting sample are shown in column 3 of Table 1 . The estimation sample includes about $40 \%$ of the individuals and firms in the overall sample of potential matches in column $2 .^{24}$

We were able to match information on the sectoral minimum wage for about $73 \%$ of the observations in the overall estimation sample. ${ }^{25}$ The resulting subsample is summarized in column 4 of Table 1. The age, gender, and earnings distributions of workers who can be matched to a sectoral minimum wage are not too different from those in the overall estimation sample. For this group we can also construct an estimate of the "wage drift" component of salary: the gap between the average daily wage and the sectoral minimum. As shown in row 7 , mean drift is 21 Euros per day - the mean percentage premium (not reported) is about $25 \%$.

Rows 10-14 of Table 1 show the mean values of various indicators of firm profitability. Row 10 reports mean value added per worker (in thousands of Euros per year). This is slightly higher in the overall sample of matches (column 2) but very similar between columns 3 and 4 . Row 11 shows the mean of value added per worker minus a crude estimate of the opportunity cost of labor, based on the average wage in the firm's ( 2 digit) industry. In the notation of our model this is $R\left(L_{t}, K_{t}, \theta_{t}\right) / L_{t}-a_{t}$, where $a_{t}$ is the industry mean wage. For comparison, row 12 shows an estimate of value added per worker minus the sectoral minimum wage (which is only

\footnotetext{
${ }^{24}$ The largest reduction in sample size comes from the year-round job requirement, which eliminates about $33 \%$ of individuals.

${ }^{25}$ As noted above, we do not have sectoral contract information for firms in the chemical industry, which is a relatively large employer in the Veneto region, and for firms in industries covered by relatively narrow sectoral agreements.
} 
available for the subsample that can be matched to contracts in column 4). Since the industry average wage is above the sectoral minimum wage, the latter is substantially larger than the former. Finally, rows 13 and 14 show an estimate of value added per worker, minus the alternative wage, minus $10 \%$ of capital per worker, i.e., $R\left(\mathrm{~L}_{t}, \mathrm{~K}_{\mathrm{t}}, \theta_{\mathrm{t}}\right) / \mathrm{L}_{\mathrm{t}}-\mathrm{a}_{\mathrm{t}}-0.1 \mathrm{~K}_{\mathrm{t}} / \mathrm{L}_{\mathrm{t}}$. Assuming there are no holdup issues, and that the user cost of capital is $10 \%$, this is an estimate of quasirent per worker. Again, we present two estimates, using either the industry average wage (row 13) or the minimum sectoral wage (row 14). A comparison of average quasi-rent per worker (using the sectoral minimum wage) to the average markup of wages over the sectoral minimum implies an estimate of $\gamma=0.25 .^{26}$ This estimate of workers' bargaining power is arguably upward-biased to the extent that firms pay higher wages for more skilled workers in a given occupation class (i.e., to the extent that wage drift includes both skill premiums and bargaining rents).

\section{Estimation Results}

\section{a. Basic Results}

As a point of departure for our analysis Table 2 presents a set of simple OLS models which relate the average wage earned by an individual worker to the components of observed quasi-rent at his or her employer and other control variables. Columns 1 and 2 show models estimated over our full estimation sample. In this sample we use the industry-wide average wage (calculated at the 2 digit level) for employees in Veneto region as our estimate of the alterative

${ }^{26}$ From equation $(10),(\mathrm{w}-\mathrm{m})=\gamma \mathrm{Q}^{*} / \mathrm{L}$, implying that a rough estimate of $\gamma$ is the ratio of the average markup of the wage over the contractual minimum wage, divided by quasi-rent per worker. To construct the ratio we multiply the mean drift in row 7 (21.2 Euros per day) times 312 working days per year and divide by quasi-rent per worker in row 14 (which is in 1000s). 
wage. Columns 3 and 4 use the subsample of observations that can be matched to a minimum sectoral wage. The baseline models in columns 1 and 3 include only the three covariates shown in the table and a set of year effects. The richer specifications in columns 2 and 4 add controls for age, tenure, gender, and foreign-born status, dummies for province and 2-digit industry, and controls for the age and total number of employees at the firm. In these models (and all other specifications in the paper) we report clustered standard errors, allowing a common component of variance at the four digit industry level (about 480 clusters).

The estimation results in Table 2 confirm that in our sample, as in other samples analyzed in the literature, wages are higher at more profitable firms. The effect of value added per worker on wages is somewhat smaller in magnitude when the sectoral minimum wage is used as a measure of outside wage opportunities, and when controls for worker and firm characteristics are added (as in columns 2 and 4), but in all cases the estimated effects are precisely estimated. The implied elasticities of wages with respect to quasi-rent per worker are reported at the bottom of the table, and center around $0.07 .{ }^{27}$ We also report the "Lester range" (Lester, 1952): the change in log wages associated with a 4-standard deviation shift in the value of quasi-rents per worker (i.e., from the bottom $5 \%$ to the top $5 \%$ of the profitability distribution, if quasi-rent per worker were normally distributed). This ranges from 18 to 22 percent.

When the sectoral average wage is used as a measure of the alternative wage, the estimated coefficients on the capital stock per worker are very close to 0 . In contrast, when we

${ }^{27}$ We estimate the elasticity by multiplying the coefficient of value-added per worker (in row 1 of the table) by the sample average value of quasi-rent per worker, assuming no holdup issues and a $10 \%$ return to capital. This is constructed as value added per worker, minus the alternative wage, minus 0.1 times capital stock per worker. An estimate of $\gamma$ can be obtained by multiplying the elasticity estimate by the ratio of wages to quasi-rents per worker (which is approximately 0.8 ). 
use the contractual minimum wage as the alternative wage, the estimated coefficients are negative, and around $10 \%$ as large (in magnitude) as the corresponding coefficients on value added per worker. The implied estimates of the user cost of capital are shown in the bottom row of the table, along with estimated standard errors (obtained by the delta method). Depending on the choice of the alternative wage, these simple OLS models suggest either complete holdup (columns 1-2) or roughly full offset of the cost of capital in the appropriate quasi-rent expression (columns 3-4). We are uncertain of the reason(s) for the discrepancy, though we believe the sectoral minimum wage is probably a better measure of the alternative wage in the Italian setting. ${ }^{28}$ Moreover, as we show below, the discrepancy disappears once we include job-match fixed effects, in which case both choices are consistent with full offset of capital costs.

While the models in Table 2 fit relatively well (the R-squared from the model in column 4, for example, is close to $50 \%$ ), and yield estimated profit-sharing effects that are comparable to those in many earlier studies, an important concern is the potential impact of unobserved heterogeneity in firm profitability and workers' skills. In particular, if more profitable firms tend to hire better-qualified workers (as suggested by Abowd, Kramarz and Margolis, 1999, for example) OLS models like those in Table 2 will overstate the causal effect of rent-sharing on wages. A number of recent studies have used matched worker-firm data to relate within-job changes in the profitability of the firm to within-job wage growth (see e.g., Margolis and Salvanes, 2001; Martins, 2009; Guertzgen, forthcoming). This approach eliminates any biases caused by permanent heterogeneity due to worker, firm, or match-specific effects.

${ }^{28}$ The difference is not due to the different samples used in columns 1-2 and 3-4. When we fit the model using the industry-average wage to the subsample for which we can match a sectoral minimum wage, the estimated coefficients on value-added per worker are very similar to the ones in columns 3 and 4 ( 0.256 and 0.257 , respectively) but the coefficients of capital per worker are small and insignificant ( -0.004 and -0.002 , respectively). 
Table 3 presents estimation results from models that include unrestricted match effects. All the models in the table also include the richer set of controls included in the even-numbered columns of Table 2. OLS models with match effects are presented in columns 1 and 3. These specifications yield relatively small (but precisely estimated) estimates of the effect of profitability on wages. Compared to models without match effects (e.g., in Table 2), the implied elasticities of wages with respect to quasi-rents, and the implied estimates of the Lester range, are reduced by a factor of 8-10. Taken at face value these models suggest that rent sharing is quantitatively unimportant in explaining wage variability in Italy.

We believe, however, that the measured response of wages to value added per worker is likely to be downward-biased by measurement errors and transitory fluctuations in value-added, particularly in specifications that include match effects. Measured value added can vary substantially from year to year depending on the timing of sales and payments for raw materials. We are also concerned that there may be some endogeneity in the relationship between wages and value added per worker, even within a job spell. To address both issues we constructed an instrument for value added per worker, based on average revenues per worker for firms in the AIDA data set in the same 4 digit industry but in other regions of Italy. This variable provides a proxy for industry-wide demand shocks that affect the profitability of employers in our sample, but should be uncorrelated with measurement errors or transitory fluctuations in value added. It is a relatively strong predictor of value added per worker for the employers in our sample (see the first stage F-statistics in row 7).

Columns 2 and 4 of Table 3 report within-spell IV estimates of our wage determination model. The IV strategy leads to a substantial increase in the magnitude of the estimated response 
of wages to value added: the implied elasticities of wages with respect to quasi rents are about one-half as large as the elasticities from the simple OLS models - in the range of 0.03 to 0.045 .

The IV estimation strategy also yields estimates of the response of wages to capital per worker that are negative, and roughly one-tenth as large in magnitude as the responses to value added per worker. (See the implied estimates of the user cost of capital in the bottom row of the table). This pattern is consistent with the predictions of a no-holdup model with a user cost of capital of approximately $10 \%$. As a check we fit a parallel set of models to those in Table 3 that impose the restriction from the no-holdup specification, and assume a $10 \%$ user cost. These restricted models fit about as those in Table 3, and yield essentially the same estimates of the elasticity of wages with respect to quasi rents, and of the Lester range in wages between high and low-profit firms.

The large increases in the estimated coefficient of value-added per worker between the OLS and IV specifications suggest that the causal effect of this variable is substantially downward-biased in the OLS models with job match dummies. A similar finding is reported by Abowd and Lemieux (1993) who estimate models of rent sharing using firm-specific wage contract data, and obtain IV estimates that are much larger than the corresponding OLS estimates. Likewise, Arai and Heyman (2004) compare OLS and IV estimates of rent-sharing in Sweden, using worker-firm data with job-match effects, and find much larger IV estimates. Finally, Guiso, Pistaferri, and Schivardi (2005) use Italian Social Security and balance sheet data from an earlier period (1984-1994) to analyze the response of earnings to firm-specific shocks in value added, allowing different effects for transitory and permanent shocks. They find that the wage response to permanent shocks is about ten times larger than the response to temporary 
shocks. While their empirical setup and identification strategy are different than ours, we believe that the permanent-transitory distinction in their results is consistent with our IV-OLS distinction, since our IV strategy identifies the response to industry-wide demand shocks, which are likely to be more persistent than firm-specific deviations from the industry mean.

\section{b. Endogeneity of Capital}

One concern with the IV estimates in Table 3 is that although we have instrumented value added per worker, we have treated capital per worker as exogenous. As a check on this assumption, we re-estimated the models, using revenues per worker for firms outside Veneto as an instrument for value added per worker and lagged capital per worker as an instrument for its current value. The use of lagged capital per worker leads to some reduction in our sample size because we lose all observations from 1995 (the first year of the AIDA data). The estimation

results, presented in Table 4, suggest that treating capital as endogenous leads to an increase in the implied estimate of the cost of capital to around 0.2 , although the estimates are relatively imprecise and we cannot reject a user cost of $10 \%$. We conclude that specifications that take capital as exogenous provide, if anything, somewhat "conservative" estimates of the offset effect of capital costs in the wage determination model.

\section{c. Allowing for Different Forms of Capital}

Holdup arises from the fixity of capital investments. Presumably, then, concerns over holdup are more relevant for some types of investments - particularly assets that are harder to liquidate - than for others. The AIDA balance sheets include information on three broad 
categories of capital: tangible fixed assets (buildings and machinery); intangible fixed assets (intellectual property, accumulated research and development investments, goodwill); and current assets or "working capital" (inventories, receivables, and liquid financial assets). To investigate the effects of different types of capital, we re-estimated the IV models in Table 3, allowing separate coefficients for measures of the amount of each type of capital per worker. The results are presented in Table 5. We find negative coefficients for all three types of capital, with the largest estimated offset effect for intangible fixed assets (implicit return $\approx 20 \%$ ), an intermediate magnitude for tangible fixed assets (implicit return $\approx 9 \%$ ), and the smallest magnitude for working capital (implicit return $\approx 3 \%$ ). The implicit user cost estimates are relatively imprecise for intangible fixed assets, and we cannot reject a specification in which we pool tangible and intangible fixed assets. The finding of a larger offset effect for fixed assets than working capital is the opposite of what might be expected if holdup is more of a problem for sunk investments than relatively liquid forms of capital. Instead, the point estimates are consistent with the idea that the user cost of working capital is relatively low, whereas the user cost for fixed investments (which are arguably riskier, and require a higher return) is higher.

\section{d. Differences by Sector}

There are a number of reasons to expect that the parameters of our wage setting model may vary across industries. For example, the extent of firm-level bargaining varies by sector. To the extent that formal contracting leads to more rent-sharing than informal bargaining, the response of individual wages to firm-specific rents will vary accordingly. The types of capital and the riskiness of investment also vary by sector, leading to potential variation in the relevant 
user cost. To explore the heterogeneity by sector we fit a series of models similar to the IV specification in Table 3, using a number of alternative classifications of industries.

As an illustration, columns 1-4 of Table 6 present a simple 3-way classification that divides workers into three (roughly equal) groups: employees at manufacturing firms with high capital-intensity; employees at low capital-intensity manufacturing firms; and employees in nonmanufacturing. ${ }^{29}$ For simplicity we only show models that use the sectoral minimum wage as the measure of the alternative wage. The results for employees in manufacturing as a whole (column 1) are quite similar to our overall results (compare the estimates to those in column 4 of Table 3). Interestingly, the results for high capital intensity manufacturing (column 2) and low capital intensity manufacturing (column 3 ) are also quite similar, and close to the pooled results. By contrast, the results for non-manufacturing industries (column 4) suggest a smaller degree of rent-sharing in this sector. Nevertheless in all three sectors the implied estimate of the user cost of capital is around $10 \%$. We conclude that there is some heterogeneity in the degree of rent sharing across industrial sectors but no strong evidence of differential holdup.

As an alternative we used the Herfindahl index (estimated by four-digit industry in each year, using AIDA data on shipments for all firms in Italy) to classify job matches as belonging to more concentrated industries (Hefindahl above the median value) or less concentrated industries (Hefindahl below the median value). We then fit versions of the IV models in Table 3 to the two subgroups. The estimates, reported in columns 5 and 6 of Table 6 , suggest that rent sharing is mainly limited to firms in high-concentration industries. In the high-concentration subsample the elasticity of wages with respect to quasi-rents is 0.07 - roughly $50 \%$ larger than in the sample

\footnotetext{
${ }^{29} \mathrm{We}$ construct an estimate of average capital per worker for each firm, and classify firms depending on whether the average is above or below the median for all firms in manufacturing.
} 
as a whole. The implied return to capital for the high-concentration sector is relatively precisely estimated at just over $10 \%$. In contrast, in the low-concentration sector there is no evidence of rent-sharing, and the implied estimate of the cost of capital is extremely imprecise.

\section{e. Debt versus Equity Financing}

In our theoretical and empirical discussions so far we have made no distinction between different sources of capital financing. A number of authors have pointed out that the use of debt financing is one way to mitigate the holdup problems that arise between workers and firms, or between suppliers and consumers of intermediate inputs (e.g., Dasgupta and Sengupta 1993; Subramaniam 1996). In the simplest version of this hypothesis it is assumed that debt holders have to be repaid before workers and owners receive any payments, implying that debt-financed capital costs are fully deducted from the quasi-rent before any rent-splitting. ${ }^{30}$ This argument suggests that an alternative explanation for our "no holdup" finding is the use of debt financing, particularly by firms that are most vulnerable to holdup. ${ }^{31}$

To test this explanation we stratified the firms in our sample into two groups: those with an above-median ratio of debt to debt-plus-equity, and those with a below-median ratio. We then fit our basic IV specification (with match-specific fixed effects) to the two sets of firms separately. We found that the estimated coefficients of our model vary between subsamples, but

${ }^{30}$ This builds on an insight about the value of pre-committing to debt in Brander and Lewis (1986). As noted by Usman (2004), an implicit assumption is that renegotiation with creditors is costly in the event of no agreement. We are grateful to Bentley MacLeod for helpful discussions on the potential importance of debt in avoiding holdup.

${ }^{31}$ Debt financing requires costly monitoring by lenders and may introduce its own moral hazard problems between managers and debt holders (Myers, 1977; Dasgupta and Sengupta, 1993). Thus, one would not expect debt financing to fully mitigate holdup. 
that the no-holdup finding is present for both types of firms. For example, using the sectoral minimum wage as a reference wage, for low-debt firms the estimated coefficient of value added per worker is 0.199 (standard error $=0.104$, and the estimated coefficient of capital per worker is -0.018 (standard error 0.011 ). By comparison, for high-debt firms the estimated coefficient of value added per worker is 0.089 (standard error=0.077), and the estimated coefficient of capital per worker is -0.012 (standard error 0.010 ). Although the estimates are relatively imprecise, in both subsamples the ratio of the capital coefficient to the value-added coefficient is very close to $10 \%$ ( $8.8 \%$ with a standard error of $3.0 \%$ for low-debt firms; $13.4 \%$ with a standard error of $4.0 \%$ for high-debt firms). Based on these results, and other specifications that include interactions between the two main coefficients and the relative share of debt in the firm's financial structure, we conclude that the absence of holdup in our sample does not does depend on the use of debt. If anything, in fact, the finding is slightly stronger for firms with relatively low levels of debt.

\section{$\underline{\text { V. Conclusions }}$}

A growing literature in many different areas of economics has emphasized the potential importance of holdup in long term relationships where binding contracts are unenforceable (see e.g., Che and Sakovics, 2008; MacLeod, 2010). Once a sunk investment is made by one party, some of the returns can be captured by the other, lowering the return to investment and potentially leading to inefficiency. As noted by Crawford (1988) under certain assumptions the holdup problem can be resolved by having the party that is not making the investment pay "up front" for the returns they will capture in future negotiations. We show that the same intuition 
applies to worker-firm bargaining. We derive an expression for the quasi-rent that is split by the bargaining parties in each period and show that it deducts the cost of the fraction of the current capital stock that is fully reversible, plus the cost of the irreversible share of the future capital stock. The sum of these deductions is approximately equal to the full cost of capital. By comparison, in the presence of distortionary holdup only a fraction of the cost of the current capital stock is deducted, and firms have an incentive to under-invest.

We then use a matched employer-employee data set from the Veneto region of Italy that contains individual earnings records and firm-specific balance sheet data to estimate within-job models of rent-sharing and test for holdup. We find strong evidence of rent sharing, with an elasticity of wages with respect to profits on the order of $3-5 \%$, mainly arising from firms in more concentrated industies. We also find that firms with higher capital per worker pay lower wages, holding constant value-added per worker. The relative size of the deduction for capital is consistent with efficient investment (i.e., no holdup) assuming a user cost of capital of around $10 \%$. The deduction is larger for tangible investments than for working capital - a pattern that is inconsistent with a higher risk of holdup for tangible investments, but consistent with a lower user cost for liquid assets. The relative magnitude of the deduction is also similar for firms with relatively low and relatively high levels of debt, suggesting that the absence of holdup is not directly attributable to the strategic use of debt financing.

There are a number of limitations of our empirical analysis that need to be kept in mind. We have no information on the presence of formal firm-level contracts, so our analysis of rent sharing represents a combination of formal and informal contracting. Our matched data set also covers a relatively short period (6 years), so we have to rely on the reported book value of 
capital, rather than on a capital series derived from past investments. Finally, the power of our instrumental variables strategy is limited and in some specifications the estimated effects of quasi-rents on wages are rather imprecise. In view of these and other limitations our findings must be interpreted with some care. Nevertheless, we believe our findings suggest that rent sharing does not necessarily lead to inefficiently low levels of investment by firms that either formally or informally share rents with their employees. 


\section{$\underline{\text { Appendix A }}$}

This appendix derives expressions for wages and other outcomes when employment is set unilaterally by the firm. As in the simpler cases described in the text, we proceed backward from the second period. Given $\mathrm{K}_{2}$ and $\theta_{2}$, the second period wage negotiation maximizes (A1) $\left[\left(\mathrm{w}-\mathrm{m}_{2}\right) \mathrm{L}_{2}\right]^{\gamma}\left[\mathrm{R}\left(\mathrm{L}_{2}, \mathrm{~K}_{2}, \theta_{2}\right)-\mathrm{wL}_{2}-\delta \mathrm{r}_{2} \mathrm{~K}_{2}\right]^{1-\gamma}$,

where $\mathrm{L}_{2}$ is endogenously determined from the labor demand schedule $\mathrm{L}_{2}\left(\mathrm{w}_{2}, \mathrm{~K}_{2}, \theta_{2}\right)$. Using the fact that $\partial \mathrm{R}\left(\mathrm{L}_{2}, \mathrm{~K}_{2}, \theta_{2}\right) / \partial \mathrm{L}_{2}-\mathrm{w}_{2}=0$, the first-order condition for $\mathrm{w}_{2}$ can be written as:

$$
\left(\mathrm{w}_{2}-\mathrm{m}_{2}\right) \mathrm{L}_{2}=\gamma /(1-\gamma) \times\left[1+\varepsilon\left(\mathrm{w}_{2}-\mathrm{m}_{2}\right) / \mathrm{w}_{2}\right] \times\left[\mathrm{R}\left(\mathrm{L}_{2}, \mathrm{~K}_{2}, \theta_{2}\right)-\mathrm{w}_{2} \mathrm{~L}_{2}-\delta \mathrm{r}_{2} \mathrm{~K}_{2}\right],
$$

where $\varepsilon$ is the elasticity of labor demand, which we assume is constant. Since $\mathrm{L}_{2}$ is endogenous, we approximate (A2) around $\mathrm{L}_{2}{ }^{*}=\mathrm{L}_{2}\left(\mathrm{~m}_{2}, \mathrm{~K}_{2}, \theta_{2}\right)$, the efficient employment level in period 2 .

We assume that

$$
\mathrm{L}_{2} \approx \mathrm{L}_{2}^{*} \times\left(1+\varepsilon\left(\mathrm{w}_{2}-\mathrm{m}_{2}\right) / \mathrm{w}_{2}\right),
$$

and use a first order approximation of the firm's profit function around the profit associated with the wage $\mathrm{m}_{2}$ :

(A4) $\mathrm{R}\left(\mathrm{L}_{2}, \mathrm{~K}_{2}, \theta_{2}\right)-\mathrm{w}_{2} \mathrm{~L}_{2} \approx \mathrm{R}\left(\mathrm{L}_{2}^{*}, \mathrm{~K}_{2}, \theta_{2}\right)-\mathrm{m}_{2} \mathrm{~L}_{2}^{*}-\mathrm{L}_{2}^{*}\left(\mathrm{w}_{2}-\mathrm{m}_{2}\right)$.

Substituting (A3) and (A4) into (A2) we obtain:

$$
\mathrm{w}_{2}=\mathrm{m}_{2}+\gamma \mathrm{Q}_{2}{ }^{*} / \mathrm{L}_{2}{ }^{*}
$$

where

$$
\mathrm{Q}_{2}{ }^{*}=\mathrm{R}\left(\mathrm{L}_{2}{ }^{*}, \mathrm{~K}_{2}, \theta_{2}\right)-\mathrm{m}_{2} \mathrm{~L}_{2}{ }^{*}-\delta \mathrm{r}_{2} \mathrm{~K}_{2}
$$

is the "efficient" quasi-rent in period 2. The optimized value of the second period bargain to workers is:

$$
\left(\mathrm{w}_{2}-\mathrm{m}_{2}\right) \mathrm{L}_{2}=\gamma \mathrm{Q}_{2}{ }^{*} \times \mathrm{L}_{2} / \mathrm{L}_{2}{ }^{*}=\gamma\left(1+\varepsilon \mathrm{g}_{2}{ }^{*}\right) \mathrm{Q}_{2}{ }^{*}
$$

where $\mathrm{g}_{2}{ }^{*}=\left(\mathrm{w}_{2}-\mathrm{m}_{2}\right) / \mathrm{w}_{2}=\gamma \mathrm{Q}_{2}{ }^{*} /\left(\mathrm{m}_{2} \mathrm{~L}_{2}{ }^{*}\right)$ is the optimized proportional wage markup. Using equation (A4), the firm's second period profits can be written as:

$$
\begin{aligned}
\pi_{2} & =\mathrm{R}\left(\mathrm{L}_{2}, \mathrm{~K}_{2}, \theta_{2}\right)-\mathrm{w}_{2} \mathrm{~L}_{2}-\delta \mathrm{r}_{2} \mathrm{~K}_{2} \\
& =\mathrm{Q}_{2}{ }^{*}-\mathrm{L}_{2}{ }^{*}\left(\mathrm{w}_{2}-\mathrm{m}_{2}\right)-(1-\delta) \mathrm{r}_{2} \mathrm{~K}_{2} \\
& =(1-\gamma) \mathrm{Q}_{2}{ }^{*}-(1-\delta) \mathrm{r}_{2} \mathrm{~K}_{2} .
\end{aligned}
$$


Turning now to the first period, the wage $\mathrm{w}_{1}$ is selected to maximize

$$
\begin{aligned}
& {\left[\left(\mathrm{w}_{1}-\mathrm{m}_{1}\right) \mathrm{L}_{1}+\beta \gamma\left(1+\varepsilon \mathrm{g}_{2}{ }^{*}\right) \mathrm{Q}_{2}{ }^{*}\right]^{\gamma}} \\
& \times\left[\mathrm{R}\left(\mathrm{L}_{1}, \mathrm{~K}_{1}, \theta_{1}\right)-\mathrm{w}_{1} \mathrm{~L}_{1}-\delta \mathrm{r}_{1} \mathrm{~K}_{1}+\beta(1-\gamma) \mathrm{Q}_{2}{ }^{*}-\beta(1-\delta) \mathrm{r}_{2} \mathrm{~K}_{2}\right]^{1-\gamma}
\end{aligned}
$$

subject to the condition that the firm selects $\mathrm{L}_{1}$ once the wage is determined. We assume that the firm selects $\mathrm{K}_{2}$ unilaterally in period 1 , anticipating the choice for $\mathrm{w}_{1}$ and $\mathrm{w}_{2}$. The first order condition for the negotiated first period wage can be written as

$$
\begin{aligned}
\left(\mathrm{w}_{1}-\mathrm{m}_{1}\right) \mathrm{L}_{1}+ & \beta \gamma\left(1+\varepsilon \mathrm{g}_{2}{ }^{*}\right) \mathrm{Q}_{2}{ }^{*}=\gamma /(1-\gamma) \times\left(1+\varepsilon\left(\mathrm{w}_{1}-\mathrm{m}_{1}\right) / \mathrm{w}_{1}\right) \\
\times & {\left[\mathrm{R}\left(\mathrm{L}_{1}, \mathrm{~K}_{1}, \theta_{1}\right)-\mathrm{wL}_{1}-\delta \mathrm{r}_{1} \mathrm{~K}_{1}-\beta(1-\delta) \mathrm{r}_{2} \mathrm{~K}_{2}+\beta(1-\gamma) \mathrm{Q}_{2}{ }^{*}\right] }
\end{aligned}
$$

Notice that if

$$
\left(1+\varepsilon_{2}^{*}\right)=\left(1+\varepsilon\left(\mathrm{w}_{1}-\mathrm{m}_{1}\right) / \mathrm{w}_{1}\right),
$$

then the terms involving $\mathrm{Q}_{2}{ }^{*}$ cancel from the both sides of $(\mathrm{A} 10)$. Since $\mathrm{g}_{2}{ }^{*}=\left(\mathrm{w}_{2}-\mathrm{m}_{2}\right) / \mathrm{w}_{2}$, this will be true if the markup of the wage over the outside wage is constant over time (or if $\varepsilon=0$ ). Assuming a constant markup, (A10) can be written as

$$
\begin{aligned}
\left(\mathrm{w}_{1}-\mathrm{m}_{1}\right) \mathrm{L}_{1}= & \gamma /(1-\gamma) \times\left(1+\varepsilon\left(\mathrm{w}_{1}-\mathrm{m}_{1}\right) / \mathrm{w}_{1}\right) \\
& \times\left[\mathrm{R}\left(\mathrm{L}_{1}, \mathrm{~K}_{1}, \theta_{1}\right)-\mathrm{wL}_{1}-\delta \mathrm{r}_{1} \mathrm{~K}_{1}-\beta(1-\delta) \mathrm{r}_{2} \mathrm{~K}_{2}\right] .
\end{aligned}
$$

This has exactly the same form as (A2) - the first order condition for $\mathrm{w}_{2}$ - and using a similar first order expansion of the profit function we get

$$
\mathrm{w}_{1}=\mathrm{m}_{1}+\gamma \mathrm{Q}_{1}{ }^{*} / \mathrm{L}_{1}{ }^{*}
$$

where

(A13) $\mathrm{Q}_{1}{ }^{*}=\mathrm{R}\left(\mathrm{L}_{1}{ }^{*}, \mathrm{~K}_{1}, \theta_{1}\right)-\mathrm{m}_{1} \mathrm{~L}_{1}{ }^{*}-\delta \mathrm{r}_{1} \mathrm{~K}_{1}-\beta(1-\delta) \mathrm{r}_{2} \mathrm{~K}_{2}$

and $\mathrm{L}_{1}{ }^{*}=\mathrm{L}_{1}\left(\mathrm{~m}_{1}, \mathrm{~K}_{1}, \theta_{1}\right)$, the efficient employment level in period 1 . Note that, as in the baseline model with fixed employment, the quasi-rent expression deducts a share $\delta$ of first period capital costs, and a (discounted) share ( $1-\delta$ ) of second period costs. Comparing (A12) to (A5), the markup of the negotiated wage over the outside alternative will be constant if the ratio of efficient quasi-rent to efficient employment is constant - a situation that we regard as plausible. ${ }^{32}$

Finally, we turn to the determination of $\mathrm{K}_{2}$, which we assume is made unilaterally by the firm, anticipating wages over the next two periods. Paralleling (A8), the firm's first period

${ }^{32}$ In a 2-period model, the quasi-rent in the second period does not include a discount for future capital costs. In a multi-period model, however, the quasi-rent in successive periods (except the last) will have the form of (A13). 
profits can be written as

$$
\pi_{1}=(1-\gamma) \mathrm{Q}_{1}{ }^{*}-(1-\delta) \mathrm{r}_{1} \mathrm{~K}_{1}+\beta(1-\delta) \mathrm{r}_{2} \mathrm{~K}_{2} .
$$

Thus,

$$
\begin{aligned}
\pi_{1}+\beta \pi_{2}= & (1-\gamma) \mathrm{Q}_{1}{ }^{*}-(1-\delta) \mathrm{r}_{1} \mathrm{~K}_{1}+\beta(1-\delta) \mathrm{r}_{2} \mathrm{~K}_{2} \\
+ & \beta(1-\gamma) \mathrm{Q}_{2}{ }^{*}-\beta(1-\delta) \mathrm{r}_{2} \mathrm{~K}_{2} \\
& =(1-\gamma)\left[\mathrm{Q}_{1}{ }^{*}+\beta \mathrm{Q}_{2}{ }^{*}\right]-(1-\delta) \mathrm{r}_{1} \mathrm{~K}_{1}
\end{aligned}
$$

which implies that the firm selects a $\mathrm{K}_{2}$ that maximizes the discounted quasi-rent. Using the definitions of $\mathrm{Q}_{1}{ }^{*}$ and $\mathrm{Q}_{2}{ }^{*}$ we obtain:

$$
\begin{aligned}
\mathrm{Q}_{1}{ }^{*}+\beta \mathrm{Q}_{2}{ }^{*}= & \mathrm{R}\left(\mathrm{L}_{1}{ }^{*}, \mathrm{~K}_{1}, \theta_{1}\right)-\mathrm{m}_{1} \mathrm{~L}_{1}{ }^{*}-\delta \mathrm{r}_{1} \mathrm{~K}_{1} \\
& +\beta\left[\mathrm{R}\left(\mathrm{L}_{2}{ }^{*}, \mathrm{~K}_{2}, \theta_{2}\right)-\mathrm{m}_{2} \mathrm{~L}_{2}{ }^{*}-\mathrm{r}_{2} \mathrm{~K}_{2}\right] .
\end{aligned}
$$

Thus, the firm's first order condition for $\mathrm{K}_{2}$ sets $\partial \mathrm{R}\left(\mathrm{L}_{2}{ }^{*}, \mathrm{~K}_{2}, \theta_{2}\right) / \partial \mathrm{K}_{2}=\mathrm{r}_{2}$, implying an efficient capital choice.

With unilateral employment-setting, $\mathrm{L}_{1}$ will differ from $\mathrm{L}_{1}{ }^{*}$, and the observed level of quasi-rent for a particular bargaining pair $\left(\mathrm{Q}_{1}\right)$ will differ from the efficient quasi-rent $\left(\mathrm{Q}_{1}{ }^{*}\right)$ that appears in the wage determination model. In particular, the observed quasi-rent implied by the model is

(A17) $\mathrm{Q}_{1}=\mathrm{R}\left(\mathrm{L}_{1}, \mathrm{~K}_{1}, \theta_{1}\right)-\mathrm{m}_{1} \mathrm{~L}_{1}-\mathrm{r}_{1} \delta \mathrm{K}_{1}-\beta(1-\delta) \mathrm{r}_{2} \mathrm{~K}_{2}$,

and, using an first-order expansion like (A4),

$$
\begin{aligned}
\mathrm{Q}_{1} & =\mathrm{R}\left(\mathrm{L}_{1}{ }^{*}, \mathrm{~K}_{1}, \theta_{1}\right)-\mathrm{m}_{1} \mathrm{~L}_{1}{ }^{*}-\mathrm{r}_{1} \delta \mathrm{K}_{1}-\beta(1-\delta) \mathrm{r}_{2} \mathrm{~K}_{2}+\left(\mathrm{L}_{1}-\mathrm{L}_{1}{ }^{*}\right)\left(\mathrm{w}_{1}-\mathrm{m}_{1}\right) \\
& =\mathrm{Q}_{1}{ }^{*}+\left(\mathrm{L}_{1}-\mathrm{L}_{1}{ }^{*}\right)\left(\mathrm{w}_{1}-\mathrm{m}_{1}\right) .
\end{aligned}
$$

Using the approximation that $\mathrm{L}_{1}=\mathrm{L}_{1}{ }^{*}\left(1+\varepsilon\left(\mathrm{w}_{1}-\mathrm{m}_{1}\right) / \mathrm{m}_{1}\right)$ and equation (A12) this can be further simplified to:

$$
\mathrm{Q}_{1}=\mathrm{Q}_{1}{ }^{*}\left(1+\varepsilon \gamma \mathrm{g}_{1}{ }^{*}\right)
$$

where $\mathrm{g}_{1}{ }^{*}=\left(\mathrm{w}_{1}-\mathrm{m}_{1}\right) / \mathrm{m}_{1}$ is the optimal first period markup. Finally, measured quasi-rent per employee is:

$$
\begin{aligned}
\mathrm{Q}_{1} / \mathrm{L}_{1} & =\mathrm{Q}_{1}{ }^{*}\left(1+\varepsilon \gamma \mathrm{g}_{1}{ }^{*}\right) /\left[\mathrm{L}_{1}{ }^{*}\left(1+\varepsilon \mathrm{g}_{1}{ }^{*}\right)\right] \\
& \approx \mathrm{Q}_{1}{ }^{*} / \mathrm{L}_{1}{ }^{*} \times\left(1-\varepsilon_{1}{ }^{*}(1-\gamma)\right)>\mathrm{Q}_{1}{ }^{*} / \mathrm{L}_{1}{ }^{*} .
\end{aligned}
$$

Thus, measured quasi-rent per worker overstates $\mathrm{Q}_{1}{ }^{*} / \mathrm{L}_{1}{ }^{*}$, the measure of quasi-rent per worker that drives wage determination, by approximately $|\varepsilon| \mathrm{g}_{1}{ }^{*}(1-\gamma)$ percent. 


\section{References}

Abowd, John M. and Thomas Lemieux (1993). "The Effects of Product Market Competition on Collective Bargaining Agreements: The Case of Foreign Competition in Canada." Quarterly Journal of Economics 108, pp. 983-1014.

Abowd, John M., Francis Kramarz, and David N. Margolis. (1999) "High-Wage Workers and High-Wage Firms." Econometrica, 67(2), pp. 251-333.

Addison, John T. and Barry T. Hirsch (1989) "Union Effects on Productivity, Profits, and Growth: Has the Long Run Arrived?" Journal of Labor Economics 7, pp. 72-105.

Arachi, Giampaolo and Federico Biagi (2005). "Taxation, Cost of Capital, and Investment: Do Tax Asymmetries Matter? Gionale degli Economisti e Annali di Economia 64 (2/3), pp. 295322.

Arai, Mahmood. (2003) "Wages, Profitability and Capital Intensity: Evidence from Matched Worker-Firm Data.” Journal of Labor Economics 21 (3), pp. 593-618.

Arai, Mahmood, and Fredrik Heyman. (2004). "Microdata Evidence on Rent-Sharing." FIEF Working Paper No. 198. Stockholm: Trade Union Institute for Economic Research (FIEF).

Baldwin, Carliss (1983). "Productivity and Labor Unions: An Application of the Theory of SelfEnforcing Contracts.” Journal of Business 56, pp. 155-186.

Becker, Gary S. (1962). "Investment in Human Capital: A Theoretical Analysis." Journal of Political Economy 70 (Supplement), pp. 9-49.

Blanchflower, David G., Andrew J. Oswald, and Peter Sanfey (1996). "Wages, Profits and Rentsharing." Quarterly Journal of Economics 111, pp. 227-251.

Brander James and Tracy Lewis (1986). "Oligopoly and Financial Structure: The Limited Liability Effect.” American Economic Review 76, pp. 956-970.

Bronars, Stephen G. and Donald R. Deere (1993) "Unionization, Incomplete Contracting, and Capital Investment.” Journal of Business; 66(1), pp. 117-32.

Brown, James N. and Orley Ashenfelter (1986). "Testing the Efficiency of Employment Contracts.” Journal of Political Economy 94 (3, Supplement), pp, pp. S40-S87.

Casadio Piero (2003), "Wage Formation in the Italian Private Sector After the 1992-93 Income Policy Agreements.” In G. Fagan, F.P. Mongelli and J. Morgan, editors, Institutions and Wage Formation in the New Europe, Cheltenham, UK: Edward Elgar, pp. 112-33.

Che, Yeon-Koo and Jozsef Sakovics (2008). "Hold-up Problem." In Steven N. Durlauf and Lawrence E. Blume, editors, The New Palgrave Dictionary of Economics, Second Edition. New 
York: Palgrave Macmillan.

Cristini, Annalisa and Riccardo Leoni (2006). "The '93 July Agreement in Italy: Bargaining Power, Efficiency Wages, or Both?” In Nicola Acocella and Riccardo Leoni, editors, Social Pacts, Employment and Growth: A Reappraisal of Ezio Tarantelli's Thought. Heidelberg: Physica-Verlag. pp. 97-122.

Christofides, Louis N. and Andrew J. Oswald (1992). "Real Wage Determination and Rentsharing in Collective Bargaining Agreements." Quarterly Journal of Economics 107, pp. 985-1002.

Connolly, Robert A., Barry T. Hirsch, and Mark Hirschey (1986). "Union Rent Seeking, Intangible Capital, and Market Value of the Firm." Review of Economics and Statistics 68 (4) pp. 567-577.

Crawford, Vincent F. (1988). "Long-Term Relationships Governed by Short-Term Contracts." American Economic Review 78 (3), pp. 485-499.

Cahuc, Pierre and André Zylberberg (2004). Labor Economics. Cambridge MA: MIT Press.

Dasgupta, Sudipto and Kunal Sengupta (1993). "Sunk Investment, Bargaining, and the Choice of Capital Structure.” International Economic Review 34 (1), pp. 203-220.

Dell'Aringa, Carlo, and Claudio Lucifora. (1994). "Collective Bargaining and Relative Earnings in Italy." European Journal of Political Economy, Vol. 10, pp. 727-47.

de Menil, George (1971). Bargaining: Monopoly Power versus Union Power. Cambridge, MA: MIT Press

Denny, Kevin and Stephen J. Nickell (1992). "Unions and Investment in British Manufacturing Industry.” British Journal of Industrial Relations 29 (1), pp. 113-121.

Dickens, William T. and Lawrence F. Katz (1986) "Industry Wage Patterns and Theories of Wage Determination." Unpublished Manuscript, University of California at Berkeley.

Elston, Julie Ann and Laura Rondi (2006). "Shareholder Protection and the Cost of Capital: Empirical Evidence from German and Italian Firms." CERIS-CNR Working Paper No. 8. Montcalieri (Italy): CERIS-CNR.

Franzosi, Alessandra M. (2008). "Costo del Capitale e Struttura Finanziaria: Valutazione degli Effecti di IRAP e DIT." Instituto per la Ricerca Sociale (Milano) Unpublished Working Paper.

Grout, Paul A. (1984). "Investment and Wages in the Absence of Binding Contracts: A Nash Bargaining Approach." Econometrica 52 (2), pp. 449-460. 
Guiso, Luigi, Luigi Pistaferri and Fabiano Schivardi (2005). "Insurance within the Firm." Journal of Political Economy 113 (5), pp. 1054-1087.

Guertzgen, N. (forthcoming). "Rent-Sharing and Collective Wage Contracts - Evidence from German Establishment-Level Data." Forthcoming in Applied Economics.

Hildreth, A.K.G. and Andrew J. Oswald (1997). "Rent-sharing and Wages: Evidence from Company and Establishment Panels." Journal of Labor Economics 15, pp. 318-337.

Hirsch, Barry T. (2004). "What Do Unions Do For Economic Performance?" Journal of Labor Research 25, pp. 417-455.

Istat (2000). "La Flessibilità del Mercato del Lavoro nel Periodo 1995-96." Informazioni 34 Roma: ISTAT.

Lester, Richard A. (1952). "A Range Theory of Wage Differentials.” Industrial and Labor Relations Review 5, pp. 483-500.

Machin, Stephen and Sushil Wadhwani (1991). "The Effects of Unions on Investment and Innovation: Evidence From WIRS.” Economic Journal 101 (405), pp. 324-330.

MacLeod, W. Bentley (2010). "Great Expectations: Law, Employment Contracts, and Labor Market Performance." In Orley Ashenfelter and David Card, editors, Handbook of Labor Economics Volume 4. New York: Elsevier, forthcoming 2010.

Manning, Alan (1987). "An Integration of Trade Union Models in a Sequential Bargaining Framework.” Economic Journal 97 (385), pp. 121-139.

Margolis, David N. and Kjell G. Salvanes. (2001). "Do Firms Really Share Rents with Their Workers?” IZA Discussion Paper No. 330. Bonn: IZA.

Martins, Pedro (2009) "Rent Sharing Before and After the Wage Bill." Applied Economics 41 (17), pp. 2133-2151.

McDonald, Ian M., and Robert Solow (1981). "Wage Bargaining and Employment." American Economic Review 71, pp. 896-908.

Myers, Stewart (1977). “The Determinants of Corporate Borrowing.” Journal of Financial Economics 4, pp. 147-175.

Nickell, Stephen J. and Sushil Wadhwani (1990). "Insider Forces and Wage Determination." Economic Journal 100(401), pp. 496-509.

Simons, Henry (1944). "Some Reflections on Syndicalism." Journal of Political Economy 52, pp. 1-25. 
Slichter, Sumner. (1950). "Notes on the Structure of Wages. Review of Economics and Statistics 32, pp. 80-91.

Smith, Adam. (1976). An Enquiry into the Nature and Causes of the Wealth of Nations, Clarendon Press, Oxford.

Subramaniam, Venkat (1996). "Underinvestment, Debt Financing, and Long-Term Supplier Relations.” Journal of Law, Economics and Organizations 12 (2), pp. 461-475.

Svejnar, Jan. (1986). "Bargaining Power, Fear of Disagreement, and Wage Settlements: Theory and Evidence from U.S. Industry." Econometrica 54 (5), pp. 1055-1078.

Tattara, Giuseppe and Marco Valentini (2007). "The Cyclical Behavior of Job and Worker Flows.” Working Paper No. 16. Department of Economics Ca' Foscari University of Venice.

Usman, Murat. (2004). "Optimal Debt Contracts with Renegotiation." Journal of Economics and Management Strategy 13 (4), pp. 755-776.

Van Reenen, John. (1996). "The Creation and Capture of Economic Rents: Wages and Innovation in a Panel of UK Companies" Quarterly Journal of Economics 111 (443), pp. 195226. 
Table 1: Descriptive Statistics for Workers, Firms and Job Matches

\begin{tabular}{|c|c|c|c|c|}
\hline & \multirow{2}{*}{$\begin{array}{c}\text { Universe of } \\
\text { Job-Year } \\
\text { Observations } \\
\text { (1) }\end{array}$} & \multirow{2}{*}{$\begin{array}{c}\text { Matched } \\
\text { Job-Year } \\
\text { Observations } \\
(2) \\
\end{array}$} & \multicolumn{2}{|c|}{ Estimation Sample } \\
\hline & & & $\begin{array}{l}\text { Full Sample } \\
(3)\end{array}$ & $\begin{array}{c}\text { Subset Matched to } \\
\text { Sectoral Contract } \\
(4)\end{array}$ \\
\hline \multicolumn{5}{|l|}{ Characteristics of Workers: } \\
\hline 1. Number of Individual Workers & $1,990,751$ & 985,160 & 416,587 & 305,364 \\
\hline 2. Percent Female & 42.3 & 34.4 & 27.3 & 26.8 \\
\hline 3. Percent Age 30 or Less & 45.6 & 39.8 & 41.3 & 42.5 \\
\hline 4. Percent Age 45 or More & 17.1 & 19.8 & 18.1 & 17.4 \\
\hline 5. Percent White Collar & 29.6 & 29.8 & 31.3 & 32.9 \\
\hline 6. Mean Daily Wage (real Euros) & 64.8 & 74.2 & 68.9 & 68.37 \\
\hline $\begin{array}{l}\text { 7. Mean Drift Component of Daily Wage } \\
\text { (real Euros) }\end{array}$ & - & - & - & 21.2 \\
\hline \multicolumn{5}{|l|}{ Characteristics of Firms: } \\
\hline 8. Number of Individual Firms & 191,202 & 18,312 & 7,283 & 5,677 \\
\hline 9. Firm Size ${ }^{a}$ & 7.0 & 36.0 & 54.4 & 54.8 \\
\hline 10. Value Added/Worker (1000's real Euros) & - & 59.7 & 44.6 & 44.5 \\
\hline $\begin{array}{l}\text { 11. Valued Added/Worker less Industry Mean Wage } \\
\text { (1000's of real Euros) }\end{array}$ & - & 31.5 & 24.4 & 20.1 \\
\hline $\begin{array}{l}\text { 12. Valued Added/Worker less Sectoral Min. Wage } \\
\text { (1000's of real Euros) }\end{array}$ & - & - & - & 30.2 \\
\hline $\begin{array}{l}\text { 13. Quasi-rent/Worker, using Industry Mean Wage } \\
\text { (1000's of real Euros) }\end{array}$ & - & 23.3 & 20.0 & 20.1 \\
\hline $\begin{array}{l}\text { 14. Quasi-rent/Worker, using Sectoral Min. Wage } \\
\text { (1000's of real Euros) }\end{array}$ & - & - & - & 26.2 \\
\hline $\begin{array}{l}\text { Characteristics of Job Match: } \\
\text { 15. Number of Job Matches }\end{array}$ & $3,111,990$ & $1,223,889$ & 452,136 & 328,824 \\
\hline 16. Mean Duration of Job (years) & 2.1 & 2.5 & 3.5 & 3.5 \\
\hline
\end{tabular}

Notes: Sample in column 1 includes observed jobs for individuals between the ages of 16 and 64 in Veneto Worker History File during a

calendar year between 1995 and 2001. Sample in column 2 includes subset of job-year observations that can be matched to AIDA balance sheet data for the firm (in the same calendar year). Estimation sample excludes part-year jobs, jobs at firms with under 15 employees, parttime jobs, jobs held by apprentices and managers, and jobs in construction and sectors with a relatively small number of AIDA firms outside Veneto. Sample in column 4 includes job-year observations that can be matched to information on the minimum wage in the relevant sectoral contract. See text for further details.

${ }^{\mathrm{a}}$ In column $1 \mathrm{firm}$ size is based on number of employees as of October in VWH data. In other columns firm size is from AIDA data. 
Table 2: OLS Estimates of Rent Sharing Model

\begin{tabular}{|c|c|c|c|c|}
\hline & \multicolumn{2}{|c|}{$\begin{array}{l}\text { Using Industry Mean As } \\
\text { Alternative Wage }\end{array}$} & \multicolumn{2}{|c|}{$\begin{array}{c}\text { Using Sectoral Minimum As } \\
\text { Alternative Wage }\end{array}$} \\
\hline & $(1)$ & $(2)$ & $(3)$ & $(4)$ \\
\hline 1. Value Added per Worker & $\begin{array}{c}0.294 \\
(0.027)\end{array}$ & $\begin{array}{c}0.275 \\
(0.026)\end{array}$ & $\begin{array}{c}0.254 \\
(0.029)\end{array}$ & $\begin{array}{c}0.247 \\
(0.028)\end{array}$ \\
\hline 2. Capital Stock per Worker & $\begin{array}{c}0.000 \\
(0.010)\end{array}$ & $\begin{array}{c}0.004 \\
(0.010)\end{array}$ & $\begin{array}{l}-0.033 \\
(0.013)\end{array}$ & $\begin{array}{l}-0.028 \\
(0.012)\end{array}$ \\
\hline 3. Alternative Wage & $\begin{array}{c}0.629 \\
(0.038)\end{array}$ & $\begin{array}{c}0.374 \\
(0.048)\end{array}$ & $\begin{array}{c}1.757 \\
(0.072)\end{array}$ & $\begin{array}{c}1.467 \\
(0.081)\end{array}$ \\
\hline 4. Additional Controls & no & yes & no & yes \\
\hline 5. R-squared & 0.223 & 0.353 & 0.445 & 0.494 \\
\hline $\begin{array}{l}\text { 6. Number of Person-Year } \\
\text { Observations }\end{array}$ & $1,395,031$ & $1,395,031$ & 984,329 & 984,329 \\
\hline \multicolumn{5}{|l|}{ Addendum: } \\
\hline Elasticity of Wages w.r.t. Rents & 0.073 & 0.068 & 0.078 & 0.076 \\
\hline Lester's Range & 0.219 & 0.206 & 0.187 & 0.182 \\
\hline Implied User Cost of Capital & $\begin{array}{c}0.000 \\
(0.035)\end{array}$ & $\begin{array}{l}-0.016 \\
(0.038)\end{array}$ & $\begin{array}{c}0.132 \\
(0.050)\end{array}$ & $\begin{array}{c}0.114 \\
(0.048)\end{array}$ \\
\hline
\end{tabular}

Notes: Dependent variable in all models is log of average daily wage. Standard errors clustered by four-digit industry in parentheses. All models include year dummies. Controls added in columns 2 and 4 are: quadratic in age, quadratic in job tenure, dummies for gender and foreign-born, and dummies for province (6) and 2-digit industry, firm age (in years) and number of firm's employees. 
Table 3: OLS and IV Within-Spell Estimates of Rent Sharing Model

\begin{tabular}{|c|c|c|c|c|}
\hline & \multicolumn{2}{|c|}{$\begin{array}{l}\text { Using Industry Mean As } \\
\text { Alternative Wage }\end{array}$} & \multicolumn{2}{|c|}{$\begin{array}{c}\text { Using Sectoral Minimum As } \\
\text { Alternative Wage }\end{array}$} \\
\hline & $\frac{\text { OLS }}{(1)}$ & $\frac{\mathrm{IV}}{(2)}$ & $\frac{\text { OLS }}{(3)}$ & $\frac{\text { IV }}{(4)}$ \\
\hline 1. Value Added per Worker & $\begin{array}{c}0.032 \\
(0.005)\end{array}$ & $\begin{array}{c}0.117 \\
(0.062)\end{array}$ & $\begin{array}{c}0.030 \\
(0.007)\end{array}$ & $\begin{array}{l}0.146 \\
(0.071)\end{array}$ \\
\hline 2. Capital Stock per Worker & $\begin{array}{l}-0.002 \\
(0.003)\end{array}$ & $\begin{array}{l}-0.012 \\
(0.007)\end{array}$ & $\begin{array}{l}-0.002 \\
(0.003)\end{array}$ & $\begin{array}{l}-0.015 \\
(0.008)\end{array}$ \\
\hline 3. Alternative Wage & $\begin{array}{c}0.011 \\
(0.009)\end{array}$ & $\begin{array}{c}0.010 \\
(0.007)\end{array}$ & $\begin{array}{c}0.801 \\
(0.035)\end{array}$ & $\begin{array}{c}0.800 \\
(0.029)\end{array}$ \\
\hline 4. Additional Controls & yes & yes & yes & yes \\
\hline $\begin{array}{l}\text { 5. Number of Person-Year } \\
\text { Observations }\end{array}$ & $1,395,301$ & $1,395,301$ & 984,329 & 984,329 \\
\hline 6. First-stage F-statistic & - & 28.2 & - & 20.3 \\
\hline \multicolumn{5}{|l|}{ Addendum: } \\
\hline Elasticity of Wages w.r.t. Rents & 0.008 & 0.029 & 0.009 & 0.045 \\
\hline Lester's Range & 0.024 & 0.087 & 0.022 & 0.108 \\
\hline Implied User Cost of Capital & $\begin{array}{c}0.074 \\
(0.098)\end{array}$ & $\begin{array}{c}0.107 \\
(0.025)\end{array}$ & $\begin{array}{c}0.058 \\
(0.111)\end{array}$ & $\begin{array}{c}0.105 \\
(0.023)\end{array}$ \\
\hline
\end{tabular}

Notes: Dependent variable in all models is log of average daily wage. All models include a complete set of job-spell dummies as well as year effects and the covariates described in Table 2 that vary within job spells. In IV models (columns 2 and 4) value-added per worker is treated as endogenous. Instrument is revenue per worker for firms in the same 4 digit industry in the same year in other regions of Italy. Standard errors clustered by four digit industry in parentheses. 
Table 4: IV Within-Spell Estimates of Rent Sharing Model, Treating Capital as Endogenous

\begin{tabular}{|c|c|c|}
\hline & $\begin{array}{l}\text { Using Industry Mean As } \\
\text { Alternative Wage } \\
(1)\end{array}$ & $\begin{array}{c}\text { Using Sectoral Minimum As } \\
\text { Alternative Wage } \\
(2)\end{array}$ \\
\hline 1. Value Added per Worker & $\begin{array}{c}0.153 \\
(0.081)\end{array}$ & $\begin{array}{c}0.147 \\
(0.105)\end{array}$ \\
\hline 2. Capital Stock per Worker & $\begin{array}{l}-0.038 \\
(0.009)\end{array}$ & $\begin{array}{l}-0.030 \\
(0.012)\end{array}$ \\
\hline 3. Alternative Wage & $\begin{array}{c}0.009 \\
(0.008)\end{array}$ & $\begin{array}{c}0.790 \\
(0.034)\end{array}$ \\
\hline 4. Additional Controls & yes & yes \\
\hline $\begin{array}{l}\text { 5. Number of Person-Year } \\
\text { Observations }\end{array}$ & $1,127,153$ & 806,348 \\
\hline $\begin{array}{l}\text { 6. First-stage F-statistic for } \\
\text { Value added per Worker }\end{array}$ & 13.9 & 10.4 \\
\hline $\begin{array}{l}\text { 7. First-stage F-statistic for } \\
\text { Capital Stock per Worker }\end{array}$ & 77.5 & 64.7 \\
\hline \multicolumn{3}{|l|}{ Addendum: } \\
\hline Elasticity of Wages w.r.t. Rents & 0.038 & 0.045 \\
\hline Lester's Range & 0.111 & 0.105 \\
\hline Implied User Cost of Capital & $\begin{array}{c}0.251 \\
(0.122)\end{array}$ & $\begin{array}{c}0.203 \\
(0.119)\end{array}$ \\
\hline
\end{tabular}

Notes: Dependent variable in both models is log of average daily wage. Models include a complete set of job-spell dummies as well as year effects and the covariates described in Table 2 that vary within job spells. Value-added per worker and capital per worker are treated as endogenous. Instruments are revenue per worker for firms in the same 4 digit industry in the same year in other regions of Italy, and lagged capital per worker at the firm. Standard errors clustered by four-digit industry in parentheses. 
Table 5: IV Within-Spell Estimates of Rent Sharing Model, Distinguishing Three Types of Capital

\begin{tabular}{lcc}
\hline & $\begin{array}{c}\text { Using Industry Mean As Alternative } \\
\text { Wage }\end{array}$ & $\begin{array}{c}\text { Using Sectoral Minimum As } \\
\text { Alternative Wage }\end{array}$ \\
\cline { 2 - 3 } & $(1)$ & $(2)$ \\
\hline 1. Value Added per Worker & 0.120 & 0.154 \\
& $(0.074)$ & $(0.080)$ \\
2. Tangible Fixed Assets per Worker & -0.011 & -0.013 \\
(plant and equipment) & $(0.007)$ & $(0.007)$ \\
3. Intangible Fixed Assets per Worker & -0.027 & -0.033 \\
(intellectual property, R\&D, goodwill) & $(0.013)$ & $(0.017)$ \\
4. Current Assets per Worker & -0.003 & -0.005 \\
(inventories, receiveables, non-fixed & $(0.007)$ & $(0.008)$ \\
financial assets, liquid funds) & & \\
& 0.010 & 0.801 \\
5. Alternative Wage & $(0.006)$ & $(0.029)$ \\
& yes & yes \\
6. Additional Controls & $1,395,301$ & 984,329 \\
7. Number of Person-Year & & 17.0 \\
Observations & 22.8 & \\
8. First-stage F-statistic & & 0.047 \\
Value added per worker & & 0.035 \\
Addendum: & 0.030 & $(0.032)$ \\
\hline Elasticity of Wages w.r.t. Rents & 0.090 & 0.087 \\
Lester's Range & 0.092 & $(0.024)$ \\
Implied User Cost - Tangible Fixed Assets & $(0.025)$ & 0.217 \\
Implied User Cost - Intangible Fixed Assets & 0.225 & $(0.114)$ \\
Implied User Cost - Current Assets & $0.134)$ & $0.047)$ \\
& & \\
\hline
\end{tabular}

Notes: Dependent variable in both models is log of average daily wage. Models include a complete set of job-spell dummies as well as year effects and the covariates described in Table 2 that vary within job spells. Value-added per worker is treated as endogenous. Instrument is revenue per worker for firms in the same 4 digit industry in the same year in other regions of Italy. Standard errors clustered by four-digit industryin parentheses. 
Table 6: IV Within-Spell Estimates of Rent Sharing Model for Different Sectors

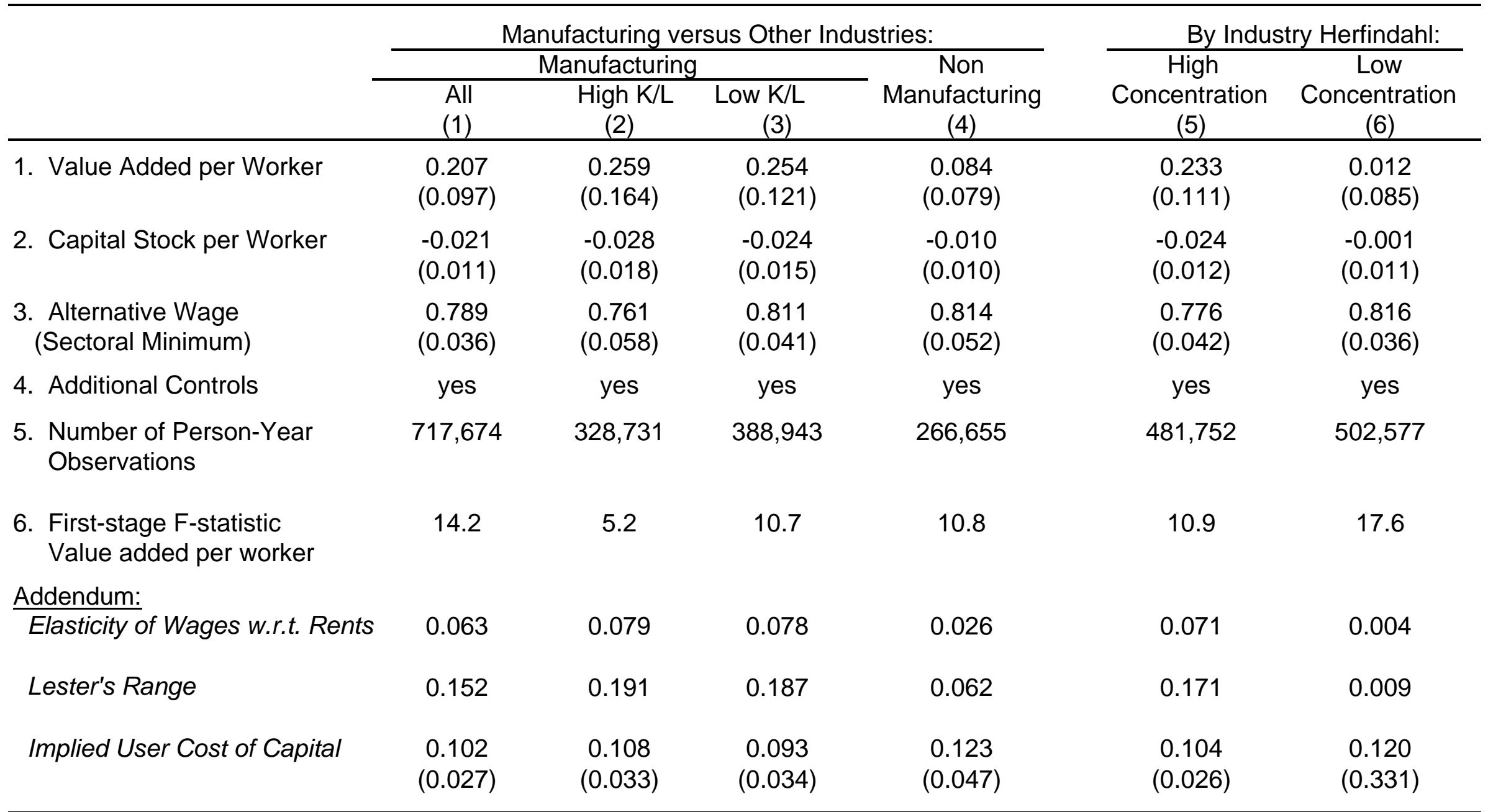

Notes: Dependent variable in all models is log of average daily wage. Models include a complete set of job-spell dummies as well as year effects and the covariates described in Table 2 that vary within job spells. Value-added per worker is treated as endogenous. Instrument is revenue per worker for firms in the same 4 digit industry in the same year in other regions of Italy. Manufacturing firms are classified as having high or low capital per worker $(\mathrm{K} / \mathrm{L})$ if their ratio of capital per worker is above or below the median for all manufacturing firms. High/low concentration classification in columns 5-6 is based on Herfindahl index of sales for 4-digit industry in all of Italy. Standard errors clustered by four-digit industry in parentheses. 